$$
\begin{aligned}
& \text { جامعـة المنصــورة } \\
& \text { كليـــة التربية }
\end{aligned}
$$

\title{
بعض السمات الشخصية لدى الموهوبين ابتكاريا
}

$$
\begin{aligned}
& \text { إعداد } \\
& \text { وليد مخلد العتيبي } \\
& \text { ضمن متطلبات الحصول على درجة دكتوراه الفلسفة في التربية } \\
& \text { (تخصص علم النفس التزبوي) }
\end{aligned}
$$

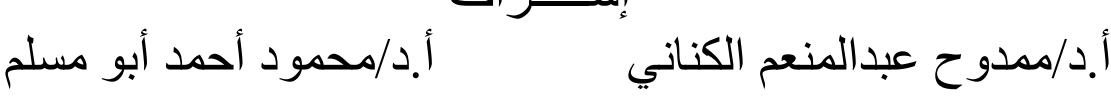

$$
\begin{aligned}
& \text { أستاذ علم النفس التربوي المتفرغ أستاذ علم النفس التربوي المتفرغ والوكيل لأسبق } \\
& \text { والعميد الأسبق لكلية التربية جامعة المنصورة بلثلية التربية جامعة المنصورة }
\end{aligned}
$$

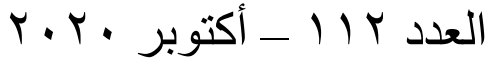




\section{بعض السمات الشخصية لدى الموهوبين ابتكاريا}

\section{وليد مخلا العتيبي}

المقدمة:

لاشك أن الاهتمام بالموهوبين والمبدعين هو من أساسيات النهضة النوعية لأي مجتمع من المجتمعات وهو مقياس لتقدم الأمم ورقيها، ويعتبر مجال الموهبة والإبداع سلسلة متكاملة، تتكون من حلقات مترابطة، أولها عملية الكثف، فإن تمت وفق خطواتها علمية سليمة وصحيحة، أمكن

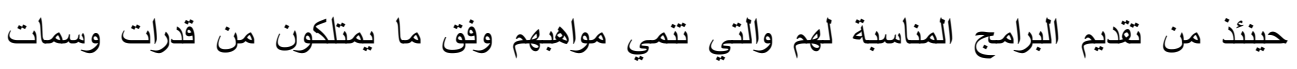

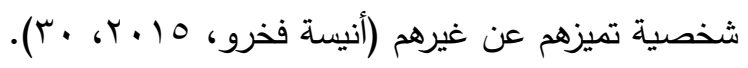

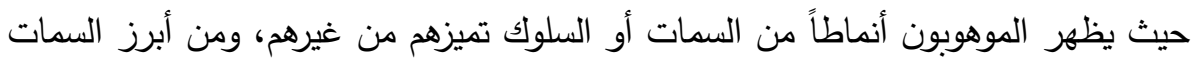

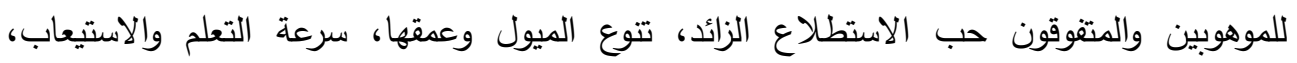

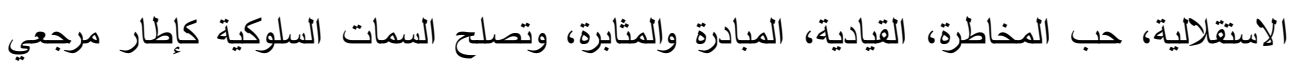
لتعريف الموهبة والتعرف على الموهوبين، حيث تم تصميم مقاييس وأدوات يستخدمها المختصين

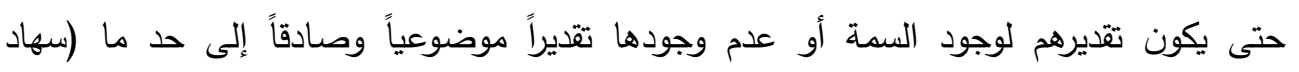

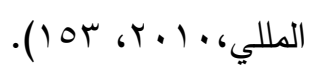

وتسهم مسألة الكثف عن السمات الثخصية المميزة للموهوبين بثكل فاعل في حل

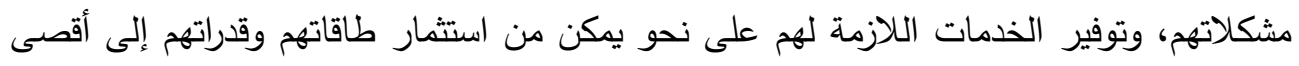

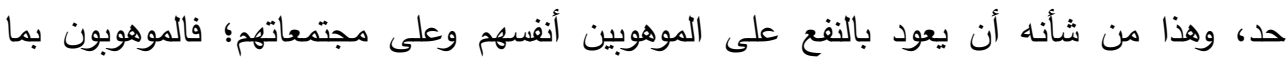

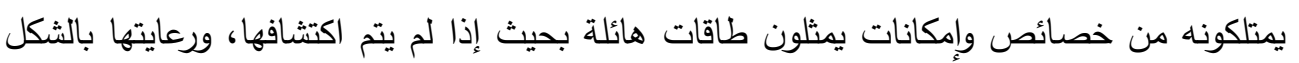

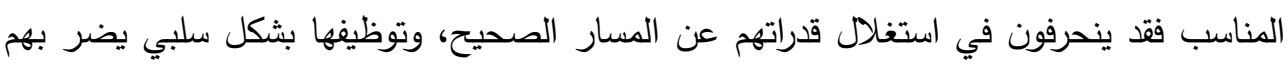

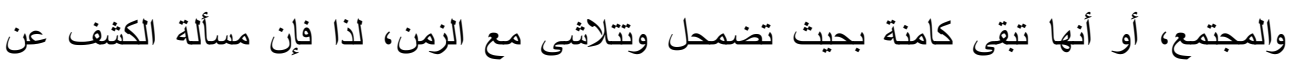

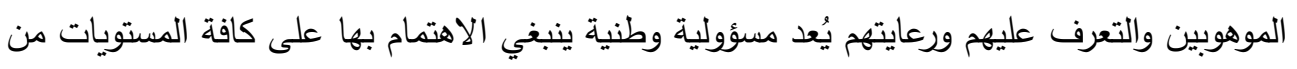
أجل استثمار طاقات هؤلاء الموهوبين، وتوجيهها التوجه الأمثل (Rimm,2011 \& Davis).

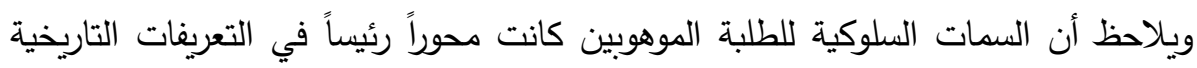

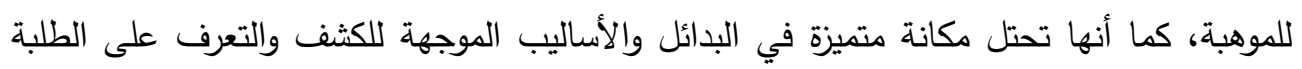
الموهوبين، وقد أقام مدخل السمات السلوكية جسراً متينا بين الدنحى السيكومترى، والمنحى السلوكي 
et al., , Renzulli(المي عملية الكثف، كما أنه وجد اهتماما واسعا من قبل الباحثين في هذا المجال

ولذلك يتعين علي المتخصصين والباحثين العمل على فهم طبيعة الموهوبين، وإعداد الأدوات

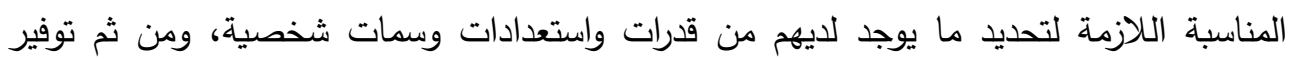

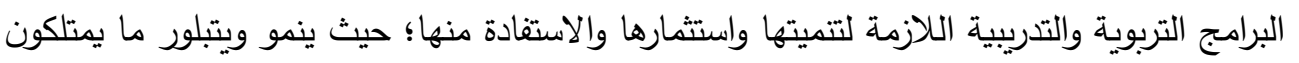
من قدرات وما يتميزون به من سمات شخصية مع عبر مراحل حياتهم إذا توافرت الظروف والعوامل

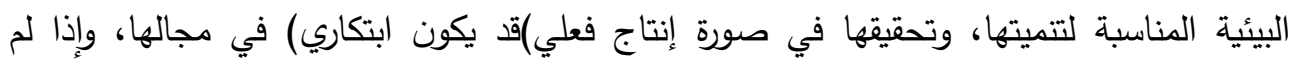
تتوافر تلك الظروف فقد تتعرض مواهبهم للاضدحلال، وقد تخبو؛ ومن ثم تضيع فائدتها على كل

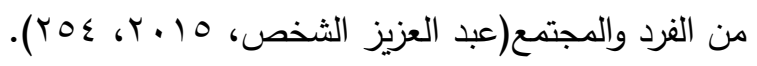

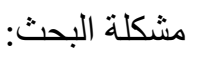

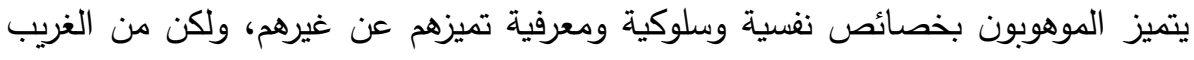

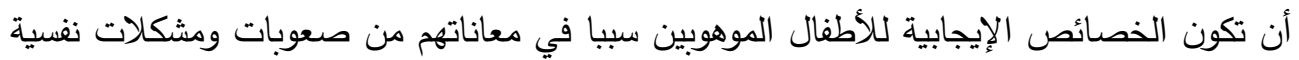

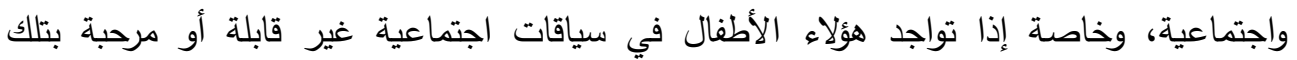

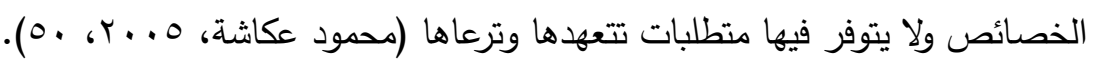
وفي ضوء ذلك يصبح من الضروري البحث في السمات الثخصية التي يمكن استخدامها للتعرف على الموهوبين، بما يساعد علي وضع الاستراتيجيات المناسبة لرعايتهم وتربيتهم على تتمية

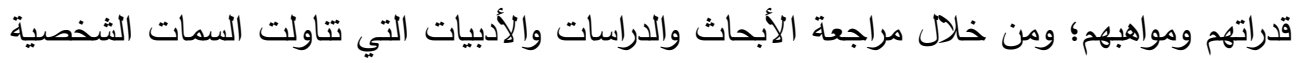

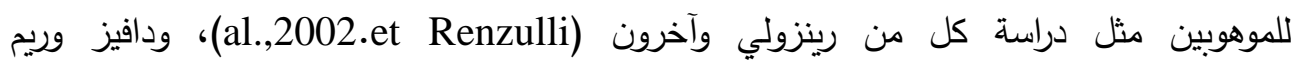

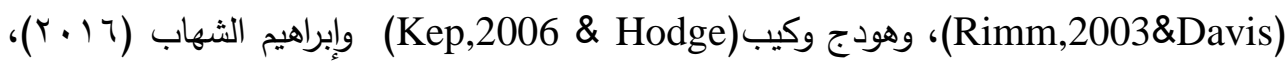
يتبين اتفاق الباحثين في مجال تعليم الموهوبين والمتفوقين على ضرورة استخدام قوائم الخصائص

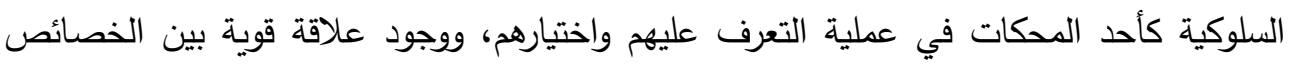

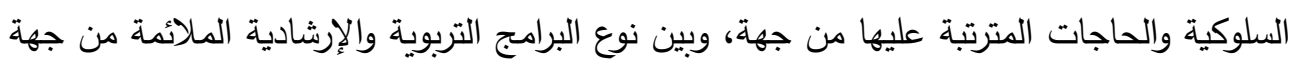
أخري، فالوضع الأمثل لخدمة الموهوب هو الذي يوفر مطابقة بين عناصر القوة والضعف وبن وبين

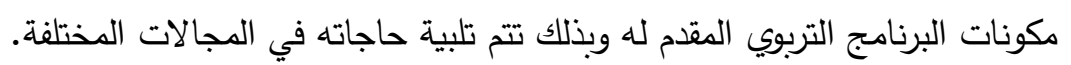
ومن ثم تكمن مشكلة البحث في الكثف عن بعض السمات الشخصية للطلاب الموهوبين ابتكاريا، والموهوبين المتميزين بقدرات ومواهب خاصة، تمكنهم من الوصول إلى مستوى أداء متميز

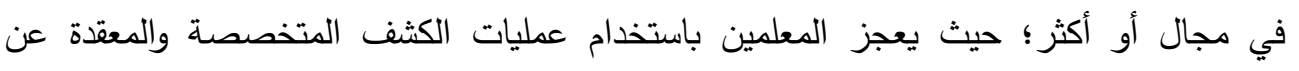


اكتثافهم واستغلال ما لديهم من طاقات ومواهب خاصة مما يجعلهم عرضة للتجاهل والإهمال، ومن

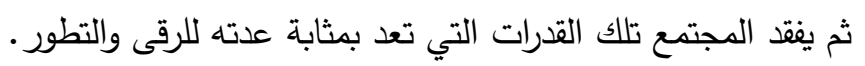
وفى ضوء ما تقدم يمكن صياغة مشكلة البحث في التساؤل الرئيسي التالي: هل توجد فروق في بعض السمات الثخصية لاى الموهوبين ابتكاريا، والموهوبين العاديين

من طلاب المرحلة الثانوية بدولة الكويت؟ والذي تتبثق منه الأسئلة الفرعية التالية:

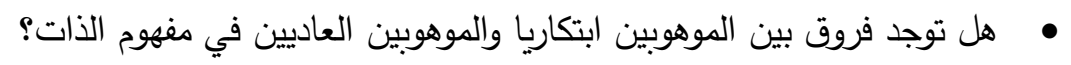

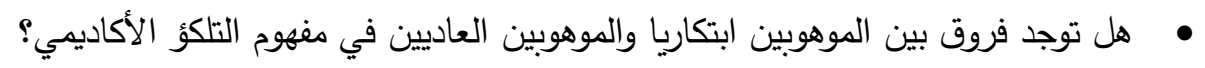

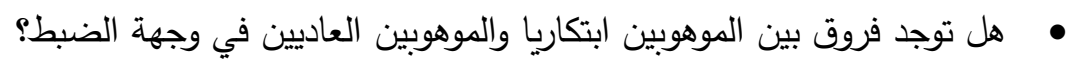

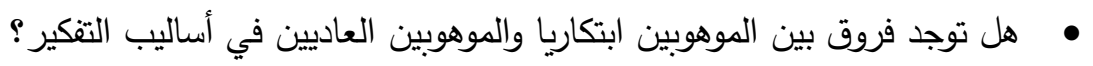

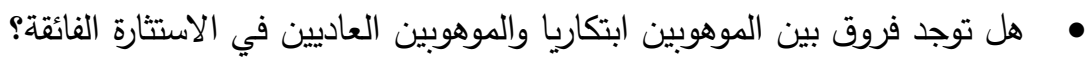

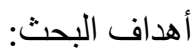
يهرف البحث الحالي إلى التحقق مما يلي: البح: • الكثـف عـن بعض السـمات الثخصـية الميـزة للطـلاب الموهـوبين ابتكاريـا، والموهـوبين العاديين.

• الكثف عن الفروق بين الطلاب الموهوبين ابتكاريا، والموهوبين العاديين في بعض السمات

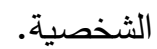

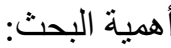
تكمن أهمية البحث الحالي فيما يلي:

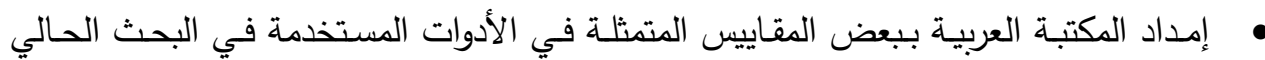
للكثف عن بعض السمات الثخصية المميزة للموهوبين ابتكاريا والموهوبين العاديين. •استخدام نتائج البحث في الكثف عن الموهوبين وإعداد برامج تدريبية وإرشادية تتاسب وما يمتلكون من السمات الشخصية، ومتابعة أداء الطالب ومدى قدرته على توظيف المعلومات والمهارات التربوية في مختلف المواقف التعليمية. •استخدام نتائج البحث في تقييم أساليب الكثف السابقة القائمة على السمات الثخصية المميزة للموهوبين، بما يضمن مراعاة التغيرات النمائية الحادثة في كافة العوامل المحيطة بالطلاب. • تقدم النتائج المعلومات والبيانات اللازمة التي تساعد واضعي الخطط التربوية ومتخذي القرار في تحسين المنظومة التعليمية بما يتوافق والمتطلبات الإنمائية للطلاب في تلك المرحلة. 


$$
\text { المصطلحات الإجر ائية للبحث: }
$$

التعريف الإجرائي للموهوبين ابتكارياً: هم طلاب الصف الثامن المتوسط مرتفعو

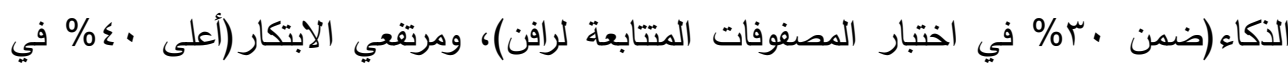
اختبار القدرة على التفكير الابتكاري).

التعريف الإجرائي للموهوبين العاديين: هم طلاب الصف الثامن المتوسط مرتفعو الذكاء

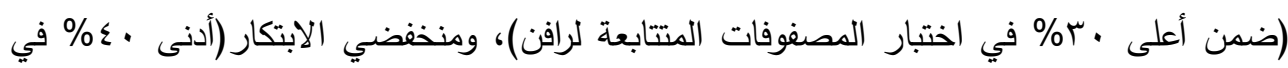
اختبار القدرة على التنكير الابتكاري).

مفهوم الذات Self-Concept: يعرف الباحث مفهوم الذات بأنه "الصورة الإدراكية التي التي

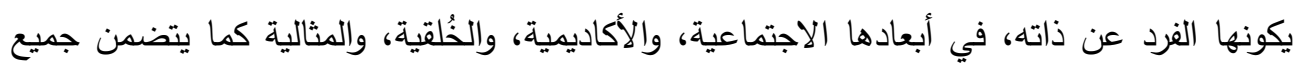

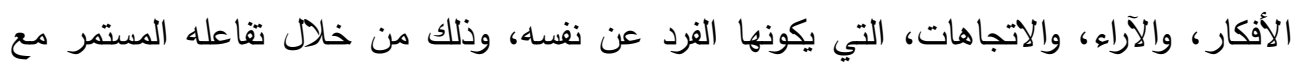

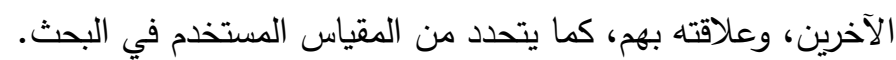

التلكؤ الأكاديمي Academic Procrastination: يعرف الباحث التلكؤ الأكاديمي بأنه "إرجاء أو تأجيل الطالب للمهام الأكاديمية الموكلة إليه، والواجب أدائها، وهذا التأجيل يتسم بالقصدية، دون وجود مبررات لذلك، على الرغم أنه يملك الوقت الكافي لأداء مهامه الدراسية، وهذه الدهاء العملية عادة ما تكون مصحوبة بمشاعر الضيق وعدم الارتياح، كما يتحدد من المقياس المستخدم في البحث.

\section{مفهوم وجهة الضبط الأكاديمية :Academic Locus of Control يعرف الباحث}

مفهوم وجهة الضبط الأكاديمي بأنه "مدى تصور الطالب وإدراكه لنتائج المهمة التي يقوم بها؛ فإذا

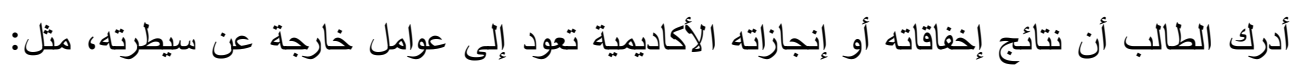

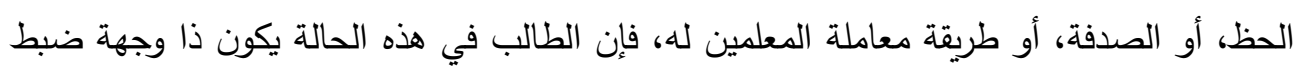

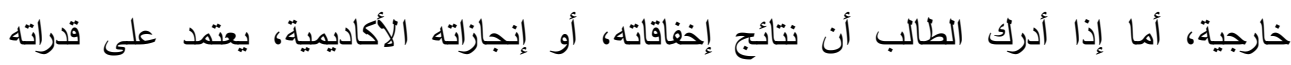

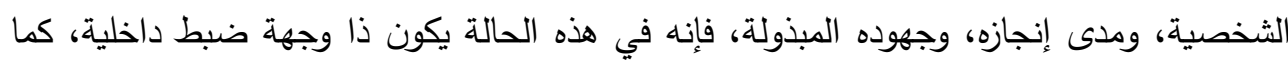

$$
\text { تتحدد من المقياس المستخدم في البحث. }
$$

أساليب التفكير Thinking Styles: اعتمد الباحث هذا التعريف في ضوء نظرية نيد

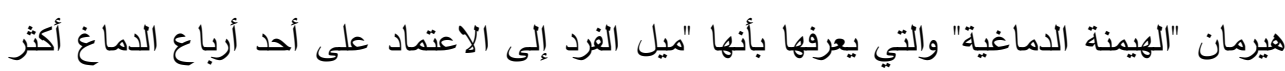

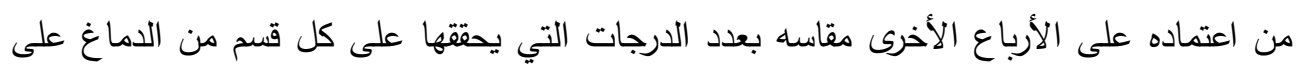

مقياس نيد هيرمان للهيمنة الدماغية (HBDI. Herrmann). 
أنماط الاستثارات الفائقة Over Excitabilities: يتبنى الباحث في هذا البحث تعريف دابروسكي(9 ا ( ) لأنماط الاستثارة الفائقة، بأنها "قدرة فائقة تظهر على شكل رد

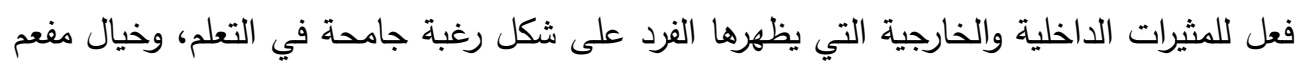

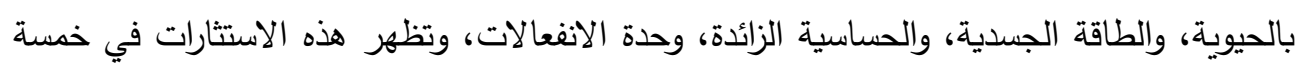

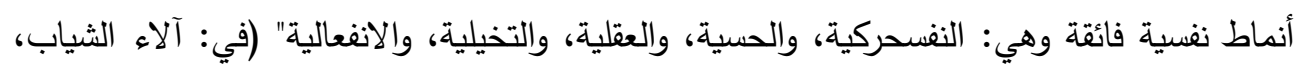

$$
\begin{aligned}
& \text { بلال الخطيب، 10 بـ ب). } \\
& \text { الإطار النظري: }
\end{aligned}
$$

يشير تعريف المنظمة العالمية للأطفال الموهوبين إلى أن الموهوب هو ذلك الثخص الذي

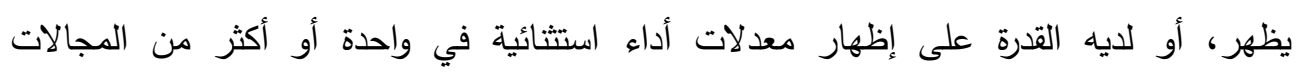

$$
\text { التعبيرية)(CAG, 2010). }
$$

ويعد تعريف الموهبة المعروف باسم الحلقات الثلاث دليلاً لعمليات الكثف والتعرف على

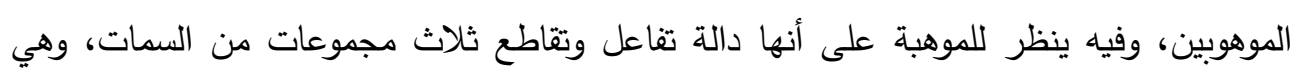
القدرات العقلية العامة التي تقع فوق المتوسط، والمستويات المرتفعة من الالتزام بالمهمات (الدافعية)،

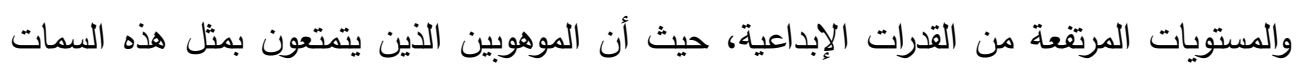

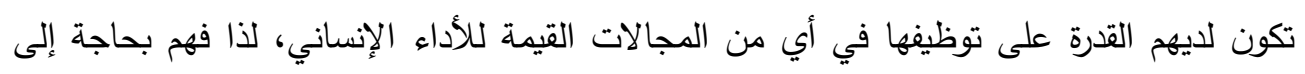

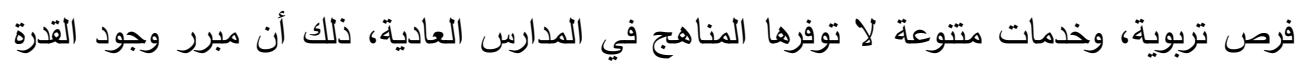

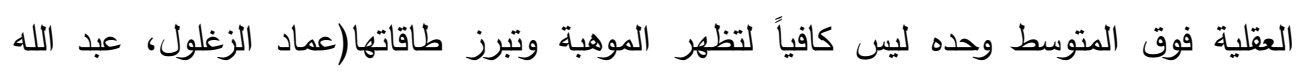

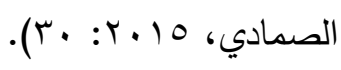

وتمر عملية الكثف عن الموهوبين ورعايتهم بمراحل أساسية، سوف نستعرضها وذلك على هلى النحو التالي:

\section{1 - مرحلة الترشيح (Nomination):}

ويتم خلالها التعرف على أولئك الأطفال الموهوبين الذين يتم ترشيحهم من قبل الأفراد الذين

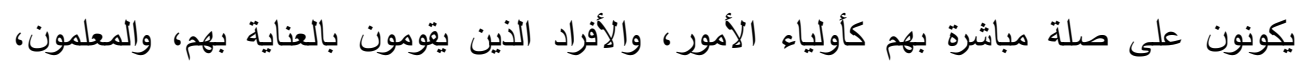

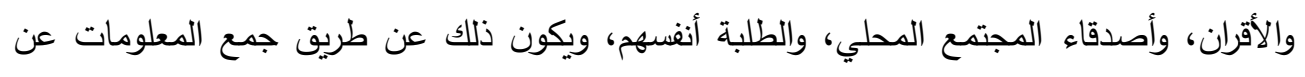

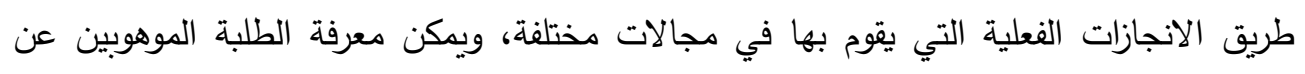
طريق قوائم الثطب (Checklists)، وخصوصاً من قبل المرشد التربوي.

r-الفحص (Screening): 
وتتطلب هذه المرحلة استخدام مقاييس يمكن أن نستكشف من خلالها الانجاز ، والكوامن، أو القدرات، والقابليات، وهي أكثر موضوعية من مرحلة الترشيح. فمثلاً يمكن معرفة الطلبة الموهوبين

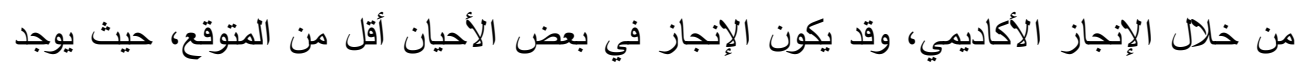

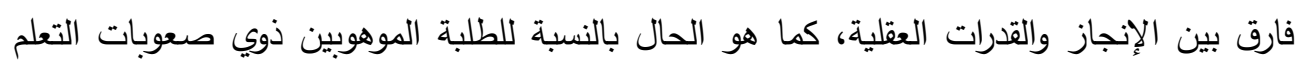

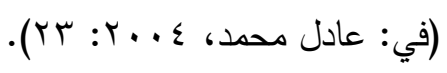

r-الرصد أو المراقبة (Monitoring):

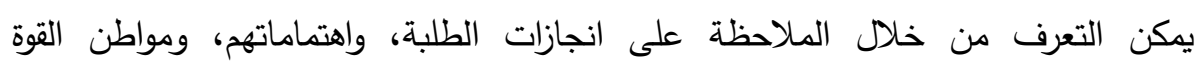
والضعف ومهاراتهم. ويمكن استخدام استمارات رسمية تساعد على تسجيل انجازات الطلبة

$$
\text { المتفوقين والموهوبين (قحطان الظاهر ، } 0 \text { ( ب ب). }
$$
خصائص الموهوبين:

يتميز الأطفال الموهوبون والمتفوقون كمجموعة بخصائص عامة، تجعلهم مختلفين عن أقرانهم من الأطفال غير الموهوبين أو غير المتفوقين، وهذه الخصائص تتسجم أصلاً مع التعاريف التي تبناها الباحثون، والإجراءات التي استخدمت للكثف عنهم، ومع الاعتراف بوجود تلك وهن

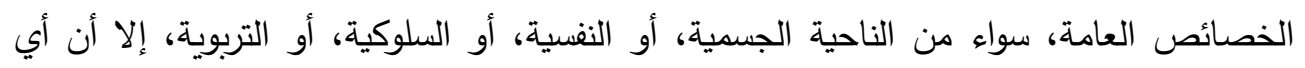
طفل موهوب أو متفوق ليس بالضرورة أن تكون لديه مثل هذه الخصائص. فكما أن الأطفال

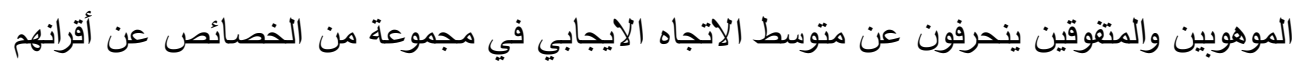
العاديين، إلا أن هناك انحرافات عن متوسط مجموعة الموهوبين والمتفوقين التي ينتمي إليها أي طفل موهوب أو متفوق. وفيما يلي عرض بعض الخصائص والسمات الثخصية والسلوكية للموهوبين: مفهوم الذات Self-Concept:

إن الذات هي المحور الرئيسي للخبرة التي تحدد شخصية الفرد، فمفهومنا عن ذواتتا أي

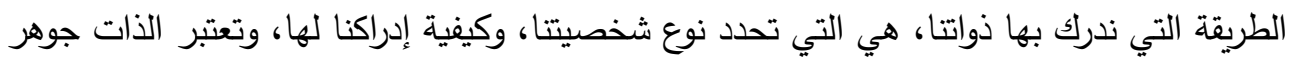
الثخصية الذي يحقق انسجامها، ومفهوم الذات حجر الزاوية فيها (مني العامرية، ـ ( ـ ب).

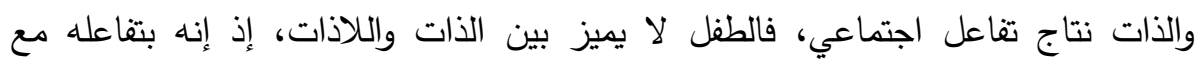

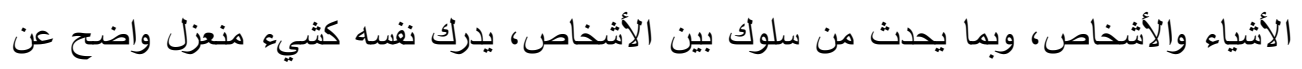

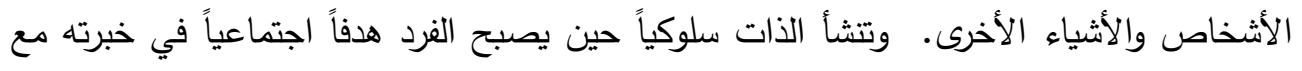

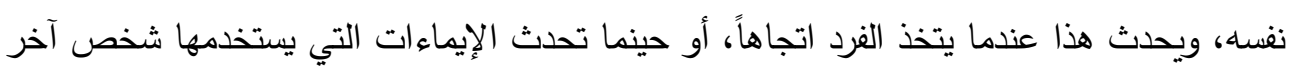


ويستجيب لها بنفسه، أو يميل إلى الاستجابة لها، فالطفل يصبح بالتدريج كائناً اجتماعياً في خبرته الخاصة، ويتصرف نحو نفسه بطريقة تضاهي تلك التي يتصرف بها نحو الآخرين(احمد جلال،

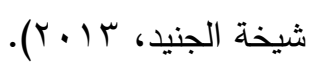

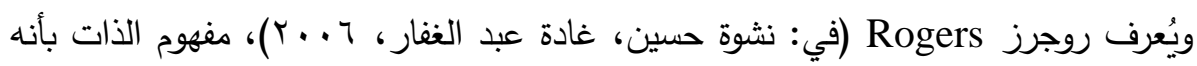
"تلك التتظيم العقلي المعرفي والمفاهيم والقيم الثعورية التي تتعلق بالسمات المميزة للفرد وعلاقاته

المتعددة".

هناك نوعان لمفهوم الذات تحدث عنهما العلماء والباحثون هما: المفهوم الايجابي للذات الذي يذهب إلى أن معرفة الفرد لذاته بشكل جيد، وتقبله لهذه الذات، والتعايش معها، يلعب دوراً

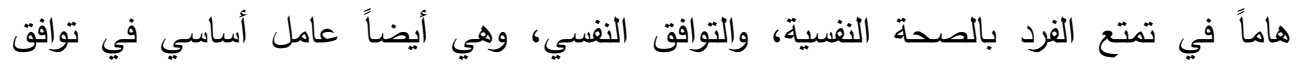
الشخصية، وتتبلنا لذاتتا بشكل جوهري، وعلى الآخرين لنا ونظرتهم لنا أيضاً. أما المفهوم السلبي

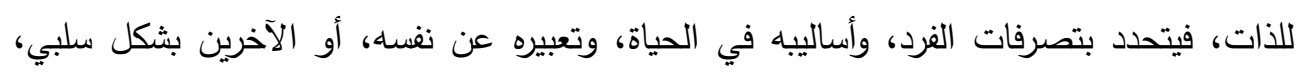

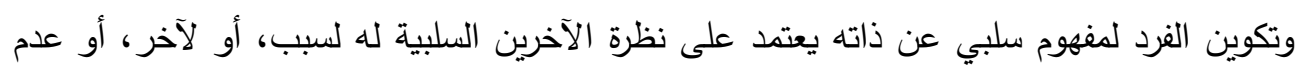

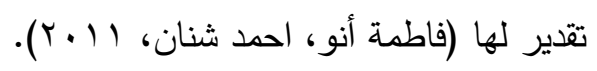

التلكؤ الأكاديمي Academic Procrastination

يُعد التلكؤ الأكاديمي من الظواهر المنتشرة في الحياة الأكاديمية، فالطالب الذي يؤجل

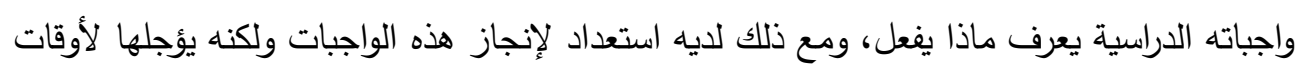

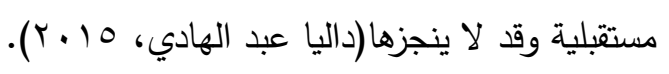

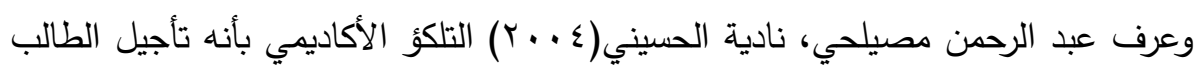

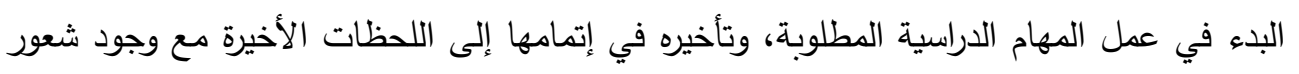

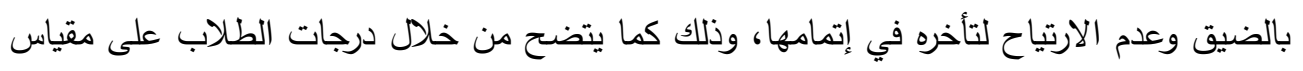

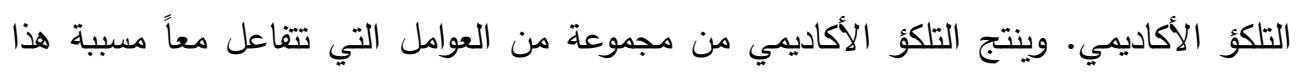

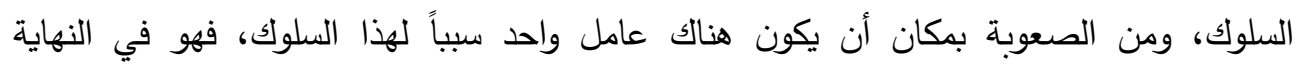

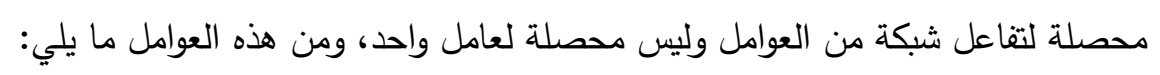
1- ضعف وعجز في القدرات التظظيمية الذاتية(Lekich,2006).

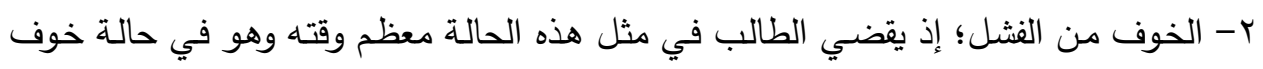

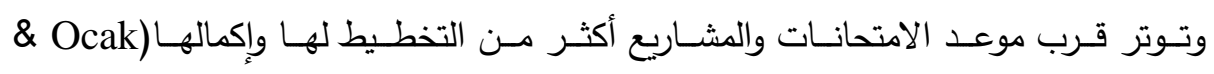

.(Boyraz,2016 
r- عدم القدرة على التركيز ، أو المستويات المنخفضة من اليقظة عند أداء المهمات، وهذا ربما

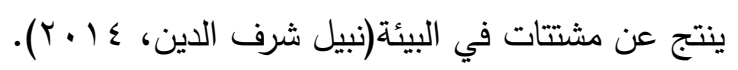

ع - انخفاض مستويات الكفاءة الأكاديمية(Jones,2013 \& Anderman).

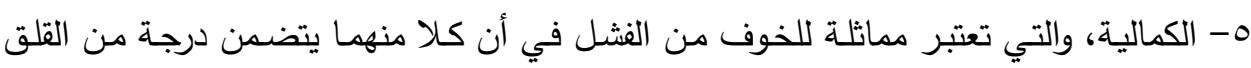

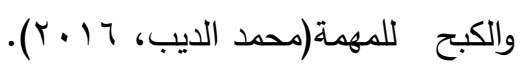

צ- عدم القدرة على إدارة الوقت(Shannon,2015 \& Mccloskey).

\section{Academic Locus of Control: مفهوم وجهة الضبط الأكاديمية إنارة الضية}

يشير هذا المفهوم إلى مدى إدراك الفرد للعلاقة السببية بين سلوكه وما يرتبط به من نتائج، فحين يُدرك الفرد أن النتائج التابعة لسلوكه ليست نتيجة لسلوكه الخاص، بل هي نتيجة لتدخل الآخرين، أو الحظ، أو الصدفة، أو أي قوى لا يمكنها فهها أو التتبؤ بها، ويعتبر مركز التحكم

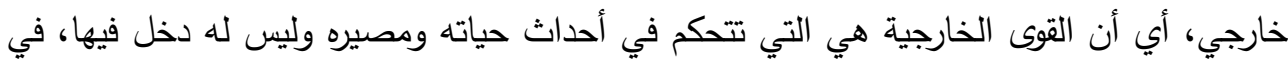

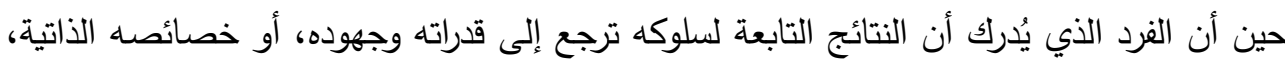

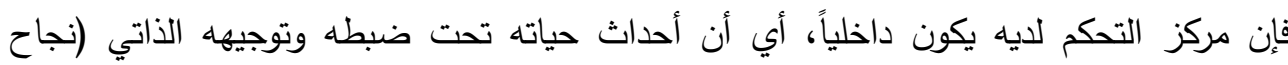

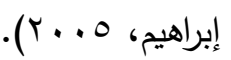

ويعرف روتر (Rotter,1966) (في: هثام مخيمر، (99V) مفهوم وجهة الضبط بأنها "توقعات الفرد المتعلقة بمصادر تعزيز السلوك فإما أن تكون هذه المصادر داخلية أو تكون مصادر

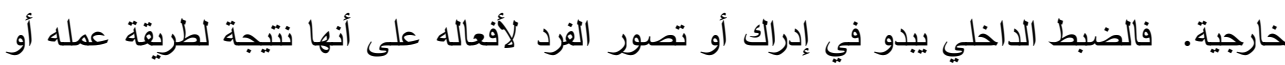

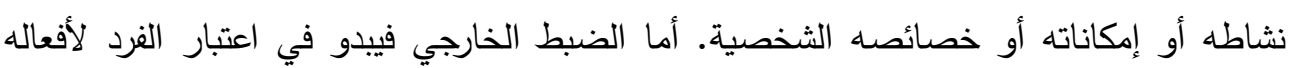

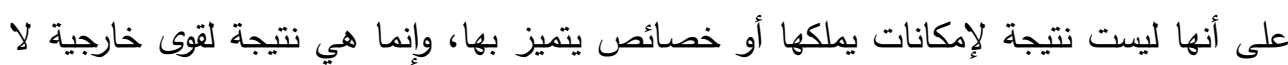
يستطيع أن يتحكم فيها.

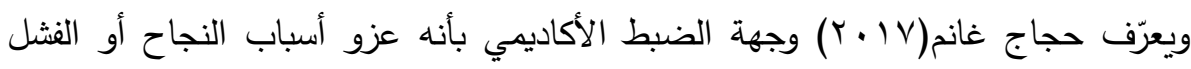

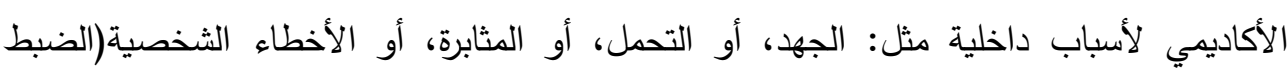

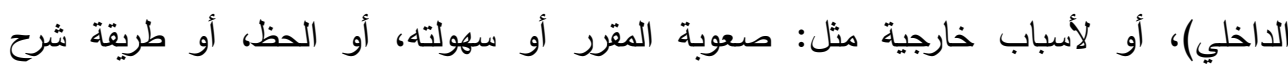

$$
\text { الأستاذ(الضبط الخارجي). }
$$

وقد أقام"روتر" فكرته الأساسية عن وجهة الضبط Locus of Control على الافتراضات

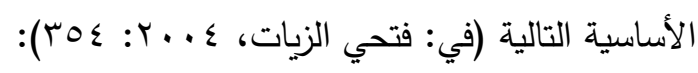

Y 1.9 
1- أن الناس يختلفون في إدراكهم وتفسيرهم للعلاقات السببية بين جهودهم الذاتية وبين النتائج البيئية المترتبة على ذلك.

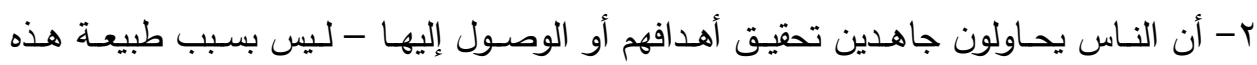

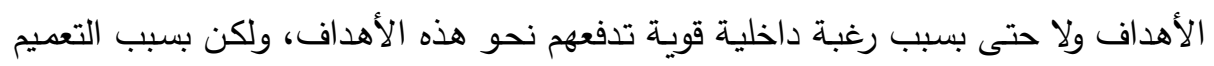

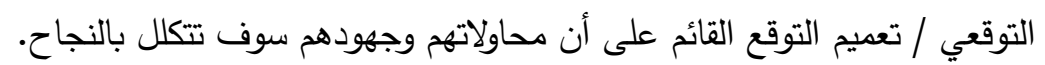

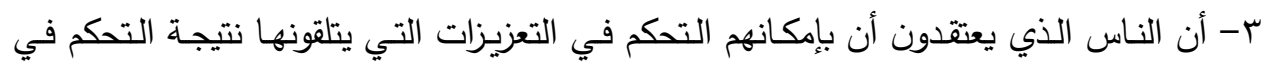
سلوكهم - وهؤلاء تختلف أنماطهم السلوكية التي تصدر عنهم عن أولئك الذين يعتقدون أنهم محكومين في سلوكهم بالحظ، أو الصدفة، أو الآخرين.

أساليب التفكير Thinking Styles:

يُعد التفكير عملية عقلية معرفية هادفة تقوم بإعادة تتظيم ما نعرفه من رموز ومفاهيم

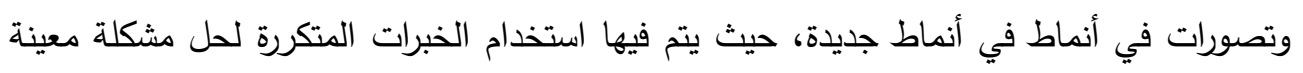
أو إدراك علاقة جديدة لموضوع ما، والتعامل مع المتغيرات الخارجية لمعرفة المعاني التي تحلها

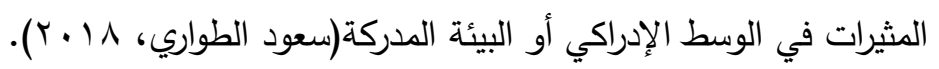

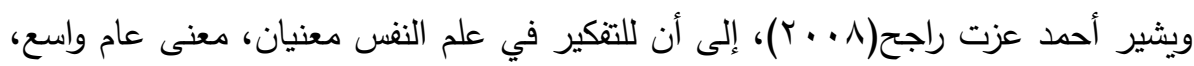

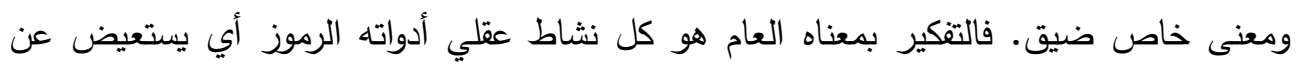

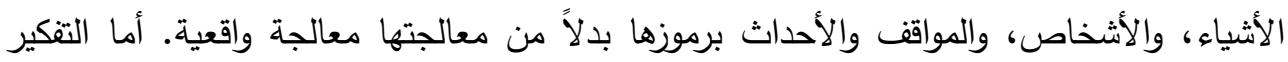

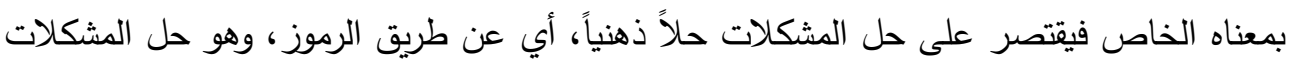
بالذهن لا بالفعل. وهذا هو ما يعرف بالتفكير الاستدلالي أو الاستدلال.

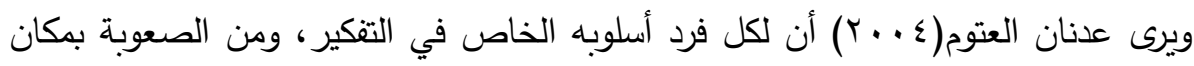
التتبؤ بطرق تفكير الآخرين، كما أن أسلوب التفكير يقيس تفضيلات الأفراد اللغوية، والمعرفية، ومستويات المرونة لديهم في العمل والتعامل مع الآخرين. نظرية نيد هيرمان" الهيمنة الدماغية"(HBDI. Hermann Brain Dominance):

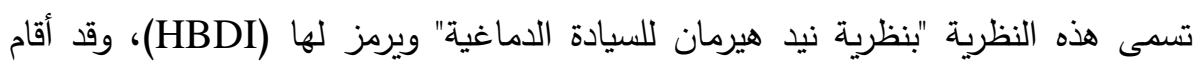

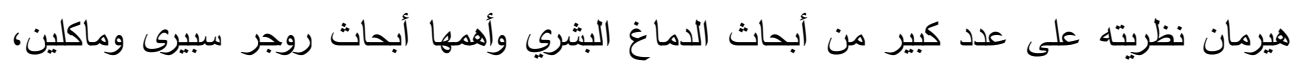

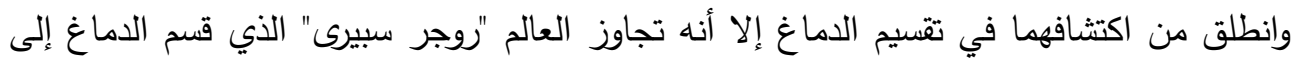

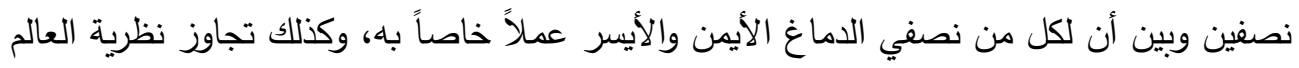

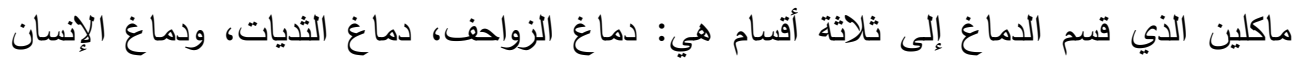


العاقل، إذ استبعد القسم الأول من الأدمغة وهو دماغ الزواحف؛ لأن المهام التي يقوم بها هذا

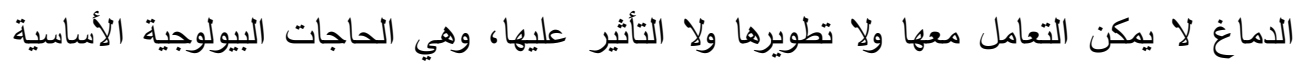
لصيرورة الحياة(محمود وضمياء، 7 ( • ب).

وقد استطاع نيد هيرمان من خلال جهوده البحثية في مجال السيادة الدماغية إلى التوصل

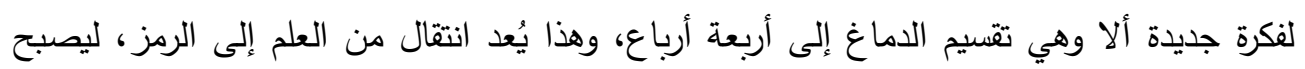
الدماغ رباعي التكوين، وأعطى لكل مربع اسماً ولوناً ومواصفات ومن هنا وهأ بدأ تفعيل فكرة الهيمنة

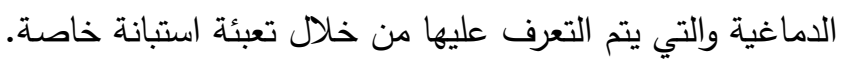

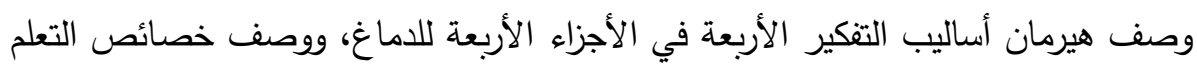

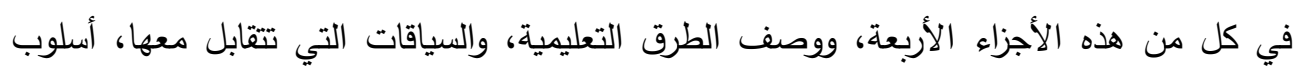
التعلم التحليلي A(الجزء الأيسر العلوي من الدماغ)،أسلوب التعلم التنفيذية (الجزء الأيسر السفلي من الدماغ)،أسلوب التعلم العاطفيC (الجزء الأيمن السفلي من الدماغ)،أسلوب التعلم الإبداعي

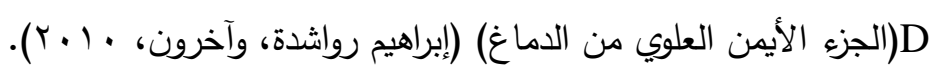

أنماط الاستثارات الفائقة Over Excitabilities:

يستند مفهوم أنماط الاستثارات الفائقة إلى نظرية الاستعدادات والإمكانات التطورية لصاحبها

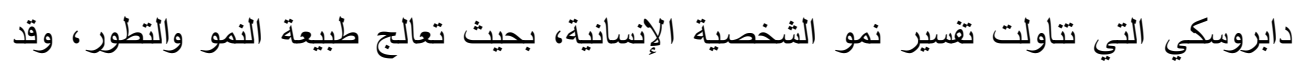

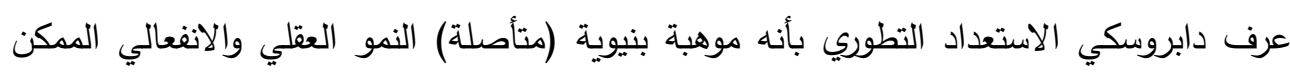

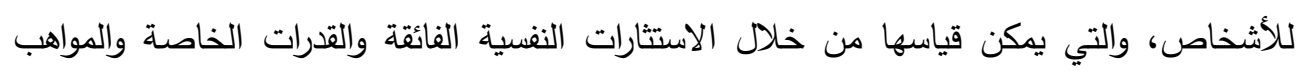

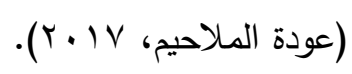

وتُعد الاستثارات الفائقة رؤى متعددة الأوجه من أجل التعرف على الخصائص المميزة للثخصية في الاستجابة للمواقف والتجارب الحياتية والسلوك بثكل عام عندما تكون ردود الاستثارة

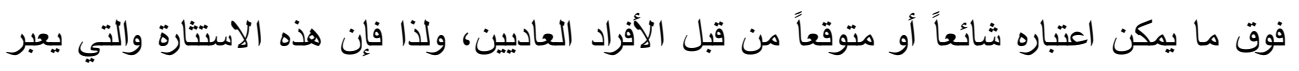

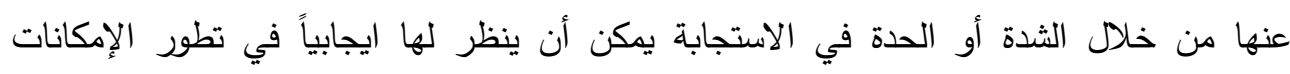

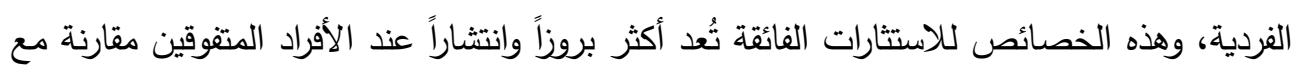

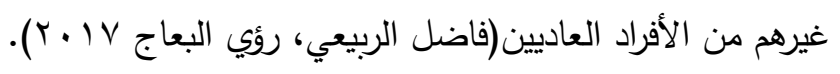

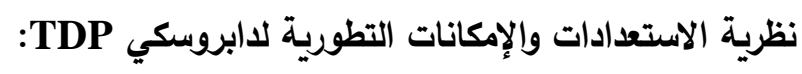

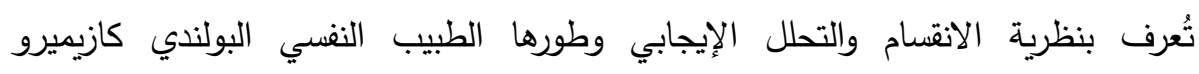
دابروسكي، وهي تعالج وبثكل مباشر طبيعة عملية النمو والتطور، وقد لاقت نظرية دابروسكي قبولاً 
واسعاً في الأوساط العلمية ذات الصلة لقيمة النظرية ومدى إثرائها وتوليدها للبحث العلمي على مدى العقود السابقة، وما يميز هذه النظرية أنها لا ترى نمو الثخصية الإنسانية نتاج ممتد لمراحل النمو الإنساني المرتبط بالعمر (Age) كما في نظرية اريكسون للنمو النفس-اجتماعي، أو ماسلو للحاجات، حي تتبنى الأطر النظرية عكس الاتجاه العام، فالقلق والتوترات والصراعات التانية النفسية والعصبية والتي يرى أنها مؤثرة بشكل سلبي تؤدي إلى انقسامات في البناء النفسي للشخصية الإنسانية، فإن منظور دابروسكي النفس- طبي يرى عكس ذلك عند الأفراد الذين يمتلكون

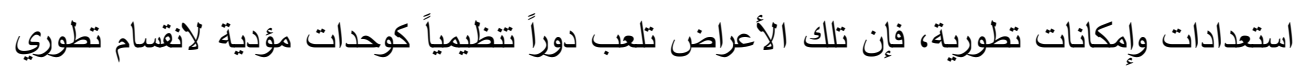

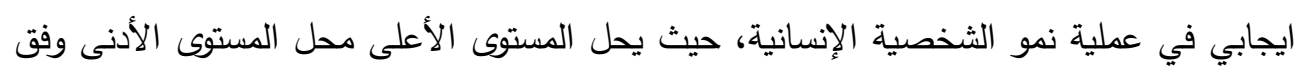

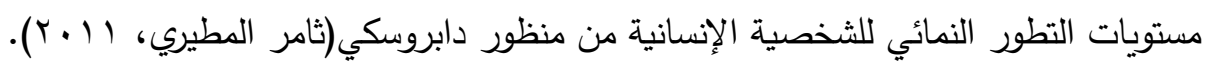

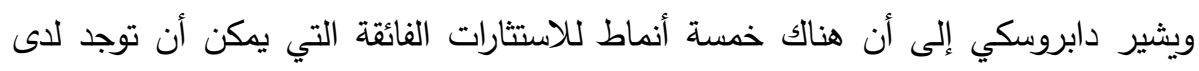

الموهوبين عقلياً وقد يتسم الثخص بنمط استثارة واحد أو أكثر، وهي كما يلي (T) Mendaglio) :(Tillier, 2006 (- الاستثارة الفائقة (لنفسحركية (Psychomotor OE)): وتعرّف بأنها "فائض من الطاقة يمكن ملاحظته من خلال الرغبة في الحركة، والكلام

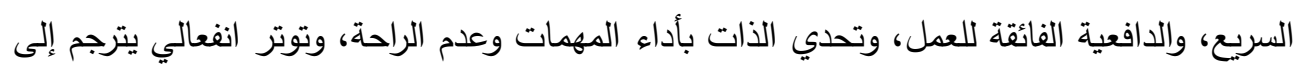
نشاط نفسيحركى كالسلوك الاندفاعي وفرط النشاط وغيرها من المظاهر الدالة". r- الاستثارة الفائقة الحسية (Sensual OE): تعرّف بأنها "الثعور والابتهاج الحسي والبحث عن وسائل حسية لتفريخ التوتر الداخلي، ومن الأن

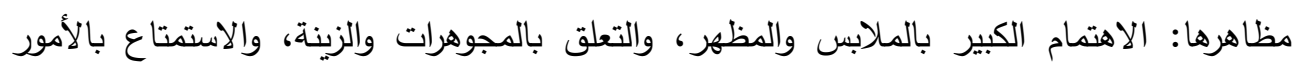

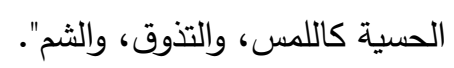
r- الاستثارة الفائقة التخيلية (Imaginational OE): ويعني هذا النوع من الاستثارة "وفرة الأفكار الخيالية، واستخدام المجاز في التعبيرات الثفهية، والأفكار الذهنية الخلاقة، كما يمكن أن يستدل عليه تثتت الانتباه، وأحلام اليقظة، والميول نحو الخيال، ويحدث لك كنتيجة لإتاحة المجال الحر للخيال". ـ - الاستثارة الفائقة العقلية (Intellectual OE): 
تعني "النشاط المكثف والمتسارع للعقل، وتعابيرها الأقوى تظهر من خلال السعي ومحاولة

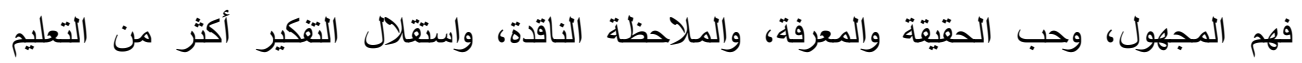

$$
\text { والتحصيل الأكاديمي بحد ذاته". }
$$

0 - الاستثارة الفائقة الانفعالية (Emotional OE)):

وهي الاستثارة الفائقة الأكثر وضوحاً من بين الأثكال الأخرى للاستثارات النفسية الفائقة،

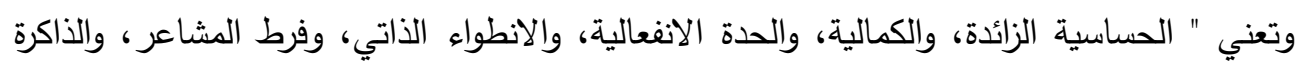
المؤثرة القويةة". در اسات سابقة مرتبطة:

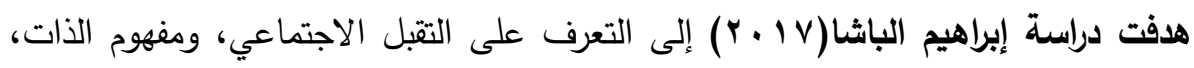

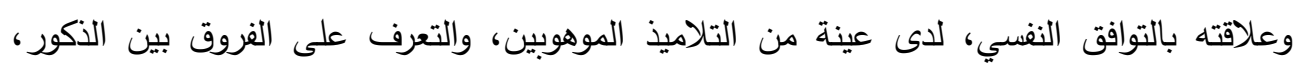

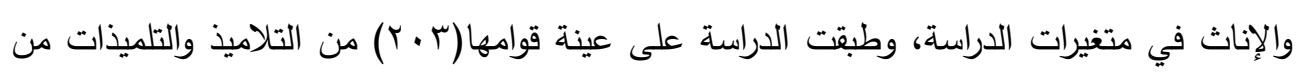

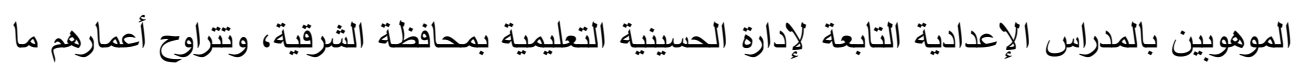

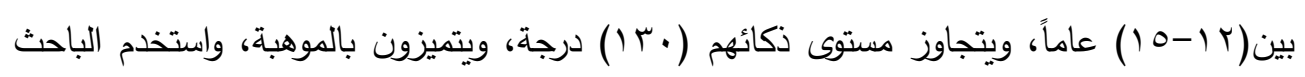

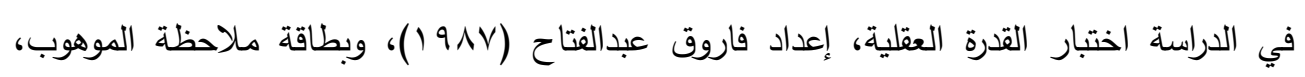

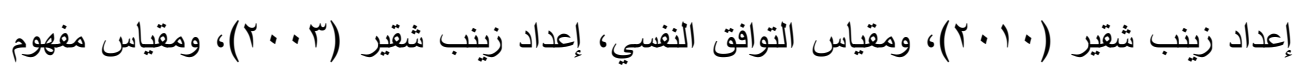

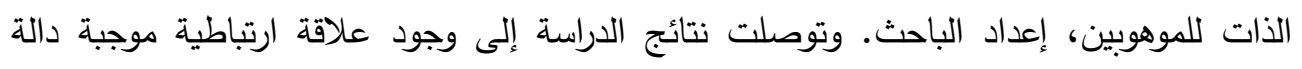

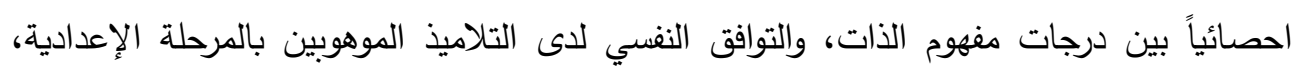

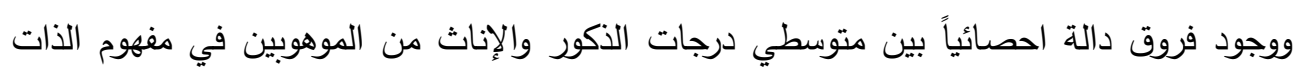
لصالح الذكور، وعدم وجود فروق دالة احصائياً بين متوسطي درجات دورات الذكور والإناث من الموهوبين في التوافق النفسي.

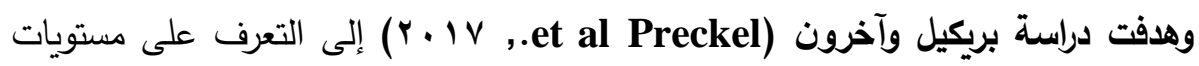
تقدير الذات، ومفهوم الذات الأكاديمي، ومفهوم الذات الفكري، ومفهوم الذات الاجتماعي، لدى على عينة

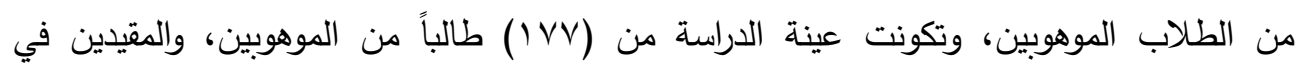

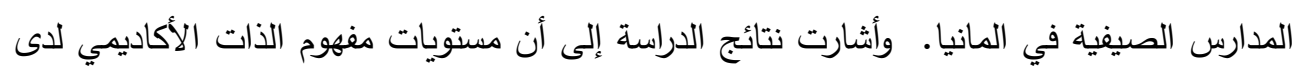

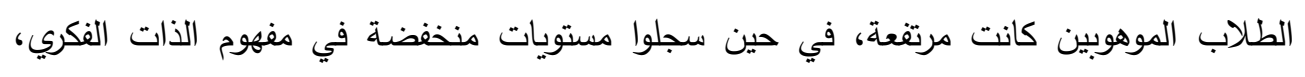

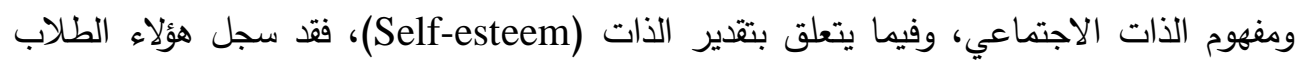
مستويات مرتفعة، وايجابية. 
وهدفت دراسة طه والثارمان(Alsharman, 2017 \& Taha) إلى التعرف على

مستويات التلكؤ الأكاديمي لدى فئتي الموهوبين، والعاديين من طلاب الصف التان التاسع، والعاشر.

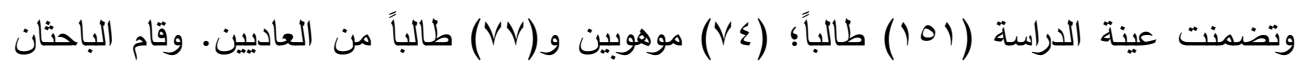

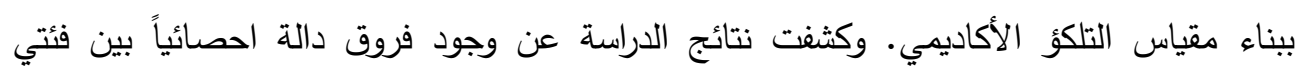

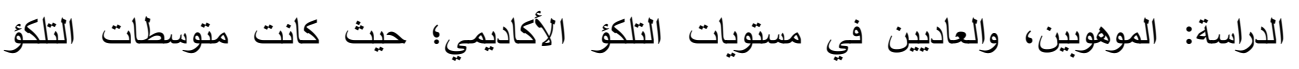

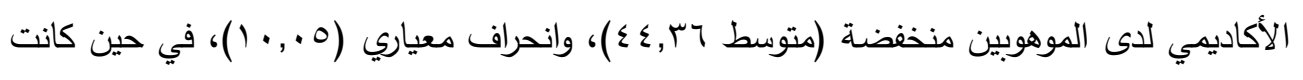
متوسطات التلكؤ الأكاديمي لاى الطلاب العاديين مرتفعة (متوسط ع 9.,.0)، وانحراف معياري $\cdot(1 \cdot, r \cdot)$

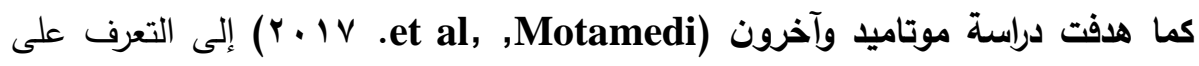
الفروق في دافعية الإنجاز ، ووجهة الضبط لاى عينة من الطلاب الموهوبين وأقرانهم من العاديين،

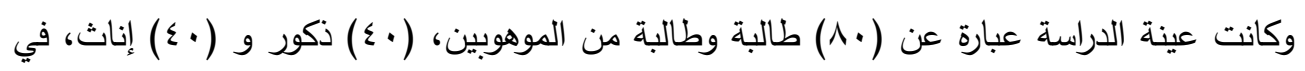

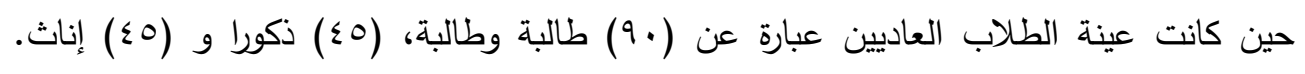
واستخدم الباحثون في هذه الدراسة مقياس وجهة الضبط لروتر ، ومقياس دافعية الإنجاز إعداد:

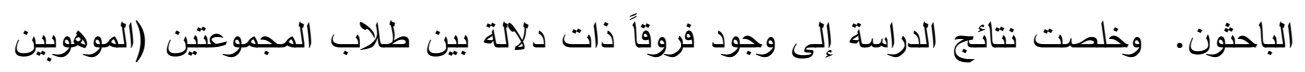

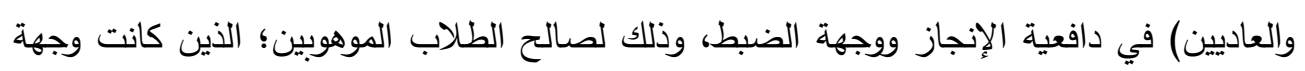
الضبط لديهم داخلية، بينما كانت وجهة الضبط لدى الإن ودهاز العاديين خارجية.

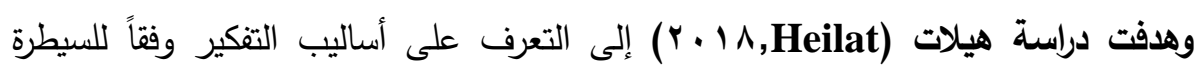

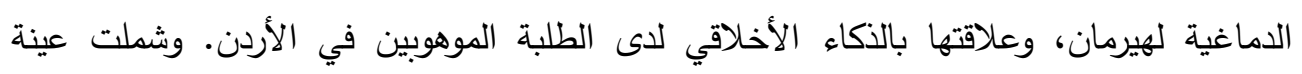

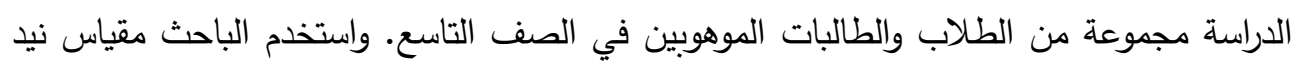

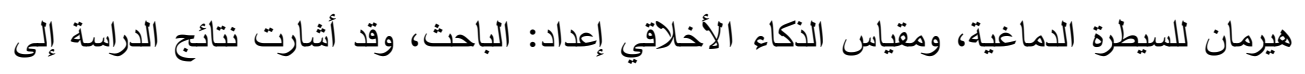

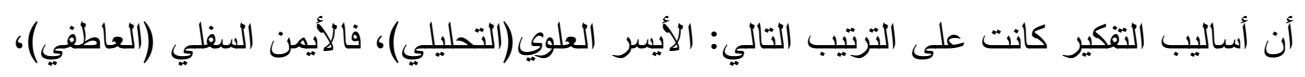

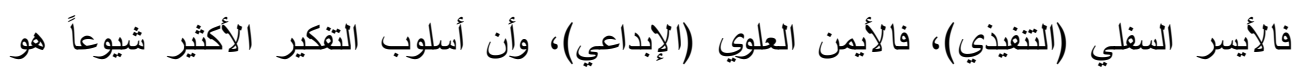

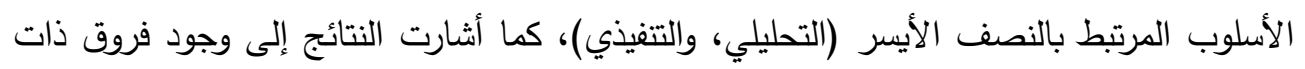

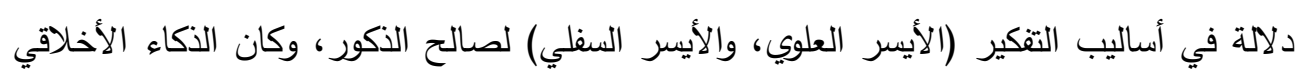

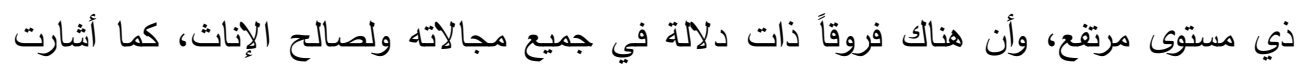

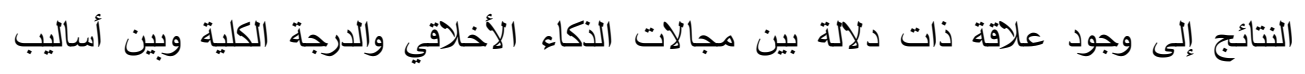
التقكير 
وهدفت دراسة فتحي جروان(11 + (1) إلى التحقق من فاعلية مقياس الاستثارات الفائقة في الكثف عن الطلبة الموهوبين، بعد التأكد من الخصائص السيكومترية له، كما تهدف إلى تعرّف

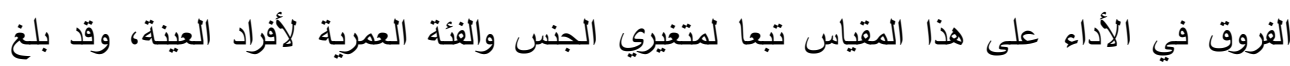

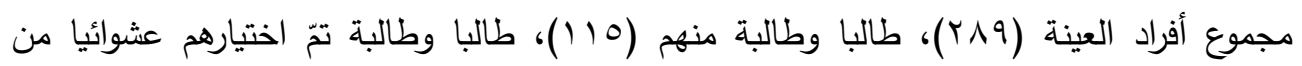

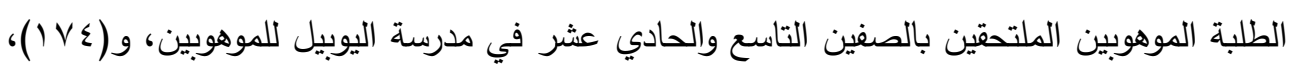
طالبا وطالبة من الطلبة العاديين من طلبة الصفين التاسع والحادي عشر في مدارس ولئ وزارة التربية

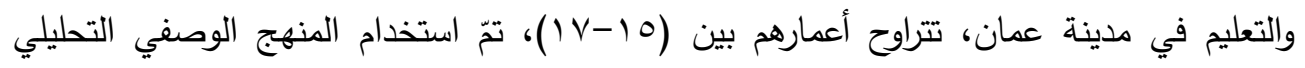

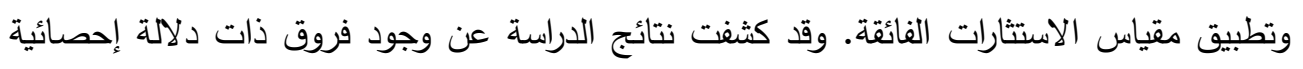
بين متوسطات الطلبة الموهوبين والعاديين لصالح الموهوبين على جميع أبعاد مقياس الاستثارات

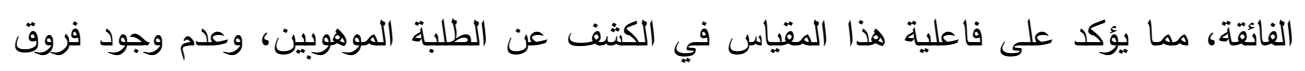
ذات دلالة إحصائية بين متوسطات الذكور والإناث على المقياس ككل وعلى فلى باقي المقاييس

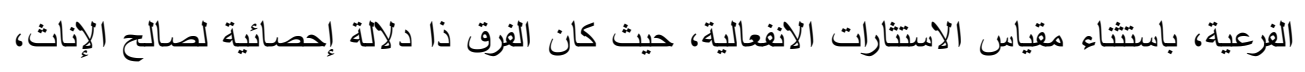

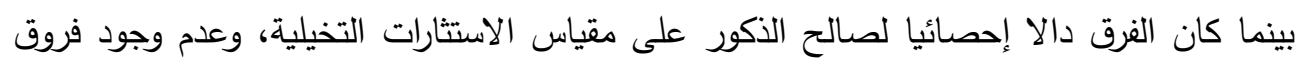
ذات دلالة إحصائية تعزى للصف أو الفئة العمرية في متوسط درجة الأداء الكلية على المقياس.

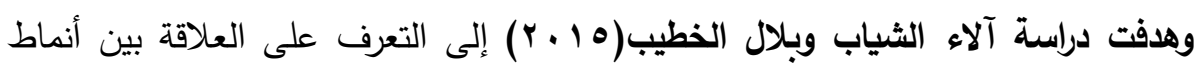
الاستثارة الفائقة (وفق نظرية دابروسكي)، وبين التفكير الإبداعي لدى الطلبة الموهوبين، والطلبة العاءية

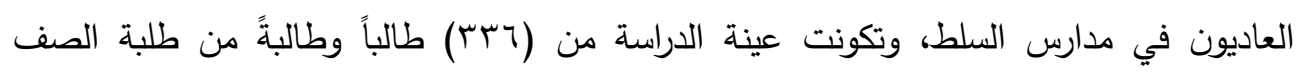
السابع، والصف التاسع في المدارس التابعة لمديرية التربية والتعليم، ومدارس الملك عبد الله الثاني

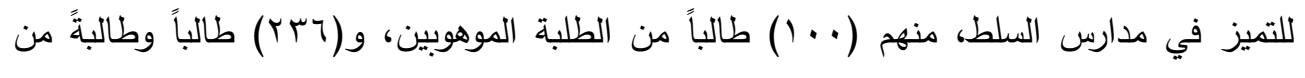
الطلبة العاديين، واستخدم الباحثون في هذه الدراسة مقياس أنماط الاستثارة الفائقة، ومقياس تورانس

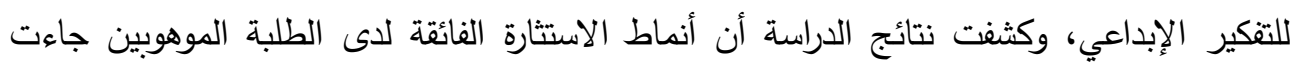

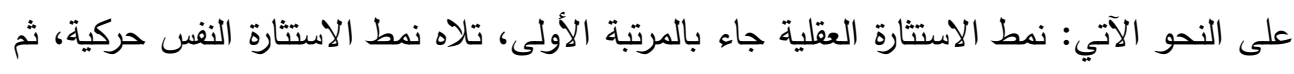

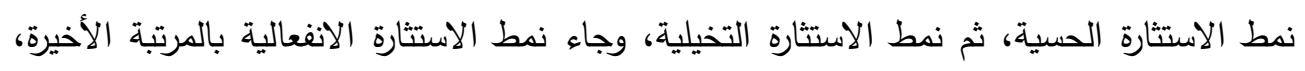

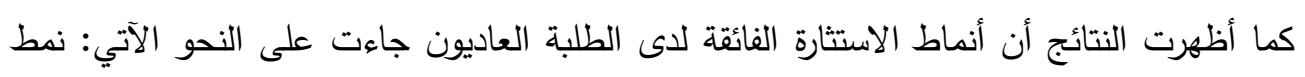

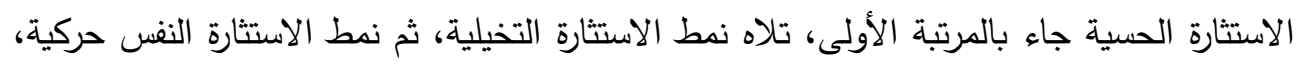

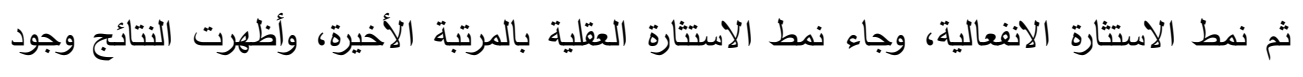

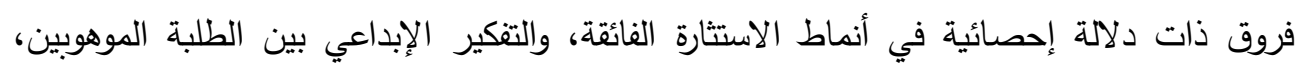


والطلبة العاديين، لصالح الموهوبين، وبينت النتائج أيضاً وجود علاقة ارتباطيه إيجابية دالة إحصائيا بين أنماط الاستثارة الفائقة، وبين التفكير الإبداعي لدى الطلبة العاديين، والطلبة الموهوبين. وتتحدد أوجه الاستفادة من الاراسات السابقة فيما يلي : • أتاحت الدراسات السابقة للباحث اختيار المنهج الملائم لبحثه، وتحديد الأساليب الإحصائية المناسبة. • ساعدت الدراسات السابقة في الجانب النظري وبلورة وتحديد متغيرات البحث من حيث زيادة المعرفة وعمقها وثرائها. • أتاحت الدراسـات السـابقة الفرصـة للاطـلاع على المقـاييس المستخدمة واختيـار المقـاييس المناسبة للبحث وتطبيقها على البيئة الكويتية.

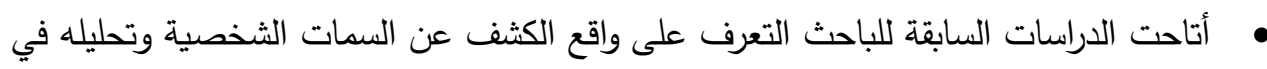
البيئة العربية خاصة، ومن ثم ضرورة إجراء البحث في البيئة الكويتية.

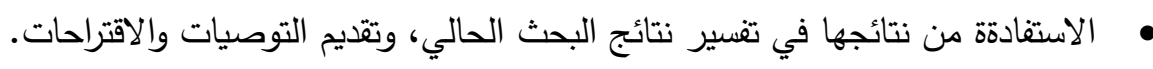
• • •اعدت الباحث في تحديد الإجراءات المناسبة للبحث، وتحديد موقع البحث الحالي، والعينة المستهدفة، وإعداد الأدوات اللازمة في البحث الحالي. فروض البحث: في ضوء الإطار النظري والدراسات السابقة يمكن صياغة فروض البحث الحالي فيما يلي: • توجد فروق ذات دلالة إحصائية بين الموهوبين ابتكاريا والموهوبين العاديين في مفهوم الذات.

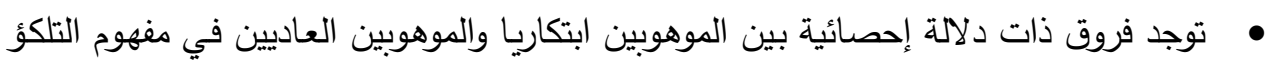
الأكاديمي. • توجد فـروق ذات دلالــة إحصـائية بين الموهـوبين ابتكاريـا والموهـوبين العـاديين في وجهـة الضبط. • توجد فروق ذات دلالــة إحصـائية بين الموهوبين ابتكاريـا والموهوبين العـاديين في أسـاليب التفكير . • توجد فروق ذات دلالـة إحصـائية بين الموهوبين ابتكاريـا والموهوبين العـاديين في الاستثارة الفائقة.

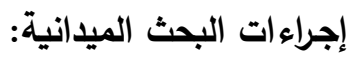


تتضمن إجراءات البحث الميدانية اختيار ووصف العينة التي أجري عليها البحث، وعرض للمقاييس المستخدمة، وخطوات إجراء البحث الحالي، والأساليب الإحصائية المستخدمة فيه.

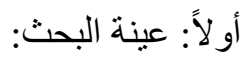

المجتمع المستهدف في هذا البحث هو طلاب الصف الثامن المتوسط (الذكور)، الملتحقين

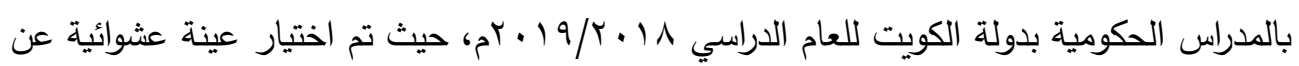

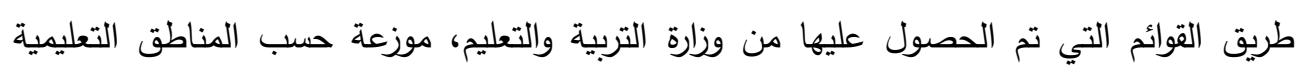
(مبارك الكبير، والفروانية، والجهراء)، بعد ذلك تم اختيار (0) مدارس من هذه المناطق التعليمية، وتم

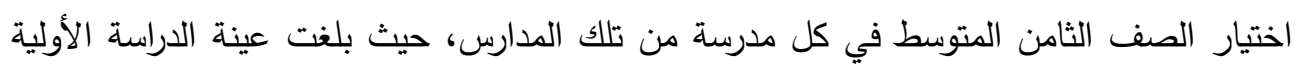
(9^r)

\section{وقام الباحث باختيار عينة البحث وفق الخطوات التالية:}

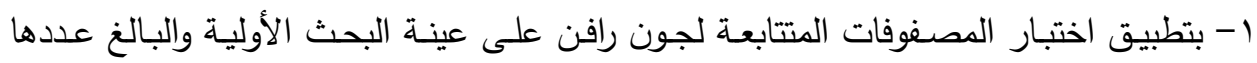

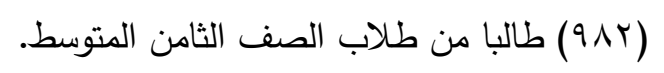

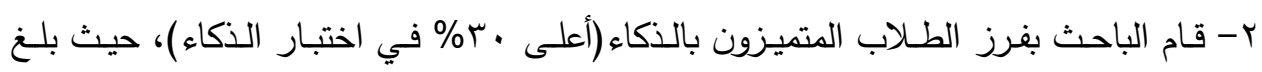

$$
\text { عددهم( ب0 ب ) طالبا. }
$$

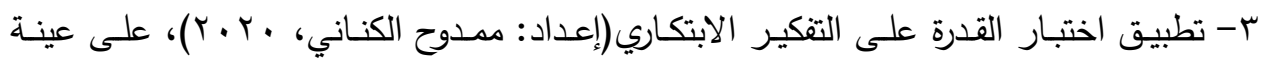

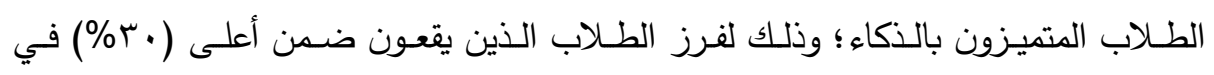

$$
\text { الابتكار ، حيث بلغ عددهم (^9) طالباً. }
$$

ع - قام الباحث بعد ذلك بتقسيم عينة الدراسة (^^) طالبا إلى مجموعتين على النحو التالي:

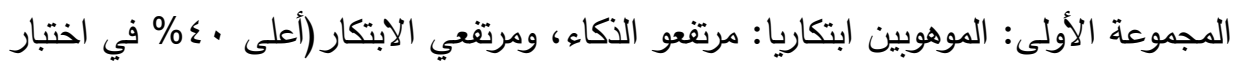

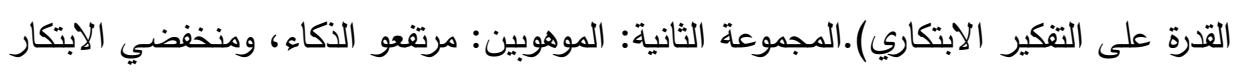

$$
\begin{aligned}
& \text { (أدنى •ـ؛ في اختبار القدرة على التنكير الابتكاري). } \\
& \text { ثانيا: المقاييس المستخدمة في البحث: }
\end{aligned}
$$

لتحقيق أهداف البحث الحالي والإجابة على تساؤلاته والتحقق من فروضه، اعتمد الباحث

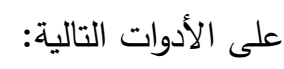

• مقياس وجهة الضبط الأكاديمي. إعداد: الباحث.

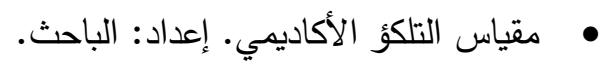

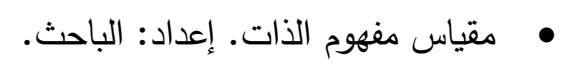




$$
\begin{aligned}
& \text { • مقياس أساليب التفكير إعداد: الباحث. }
\end{aligned}
$$

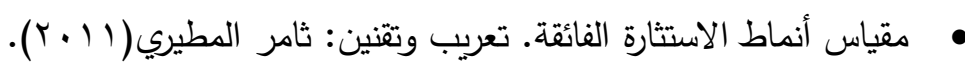

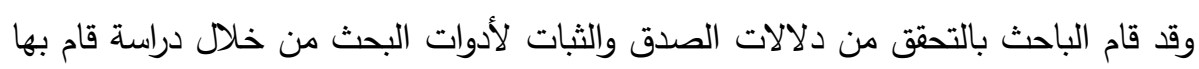

ضمن متطلبات الحصول على درجة دكتوراة الفلسفة في التربية (تخصص: علم النفس التربوي).

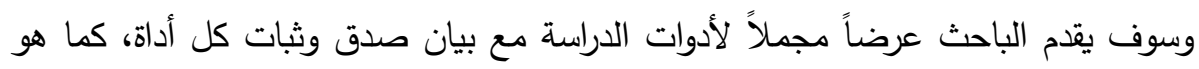

مبين في جدول (1) - c) (1)

\section{جدول (1) دلالات صدق وثبات أدوات الدراسة.}

\begin{tabular}{|c|c|c|c|c|c|}
\hline مقياس أنماط الاستثارة & مقياس أسائيب التفكير & مقياس مفهوم الذات & مقياس التلكؤ & مقياس وجهة الضبط & التقنين \\
\hline 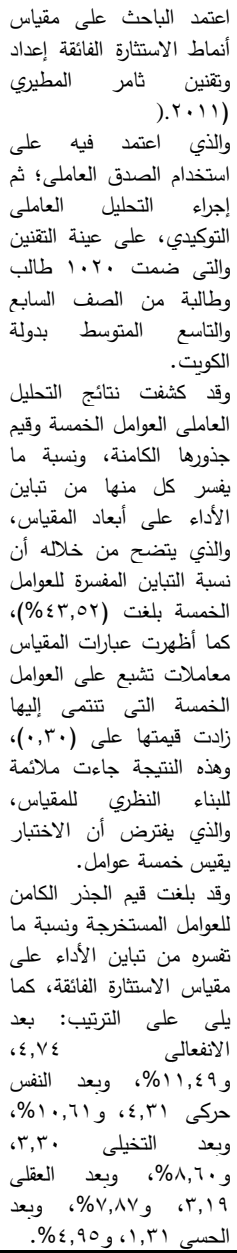 & 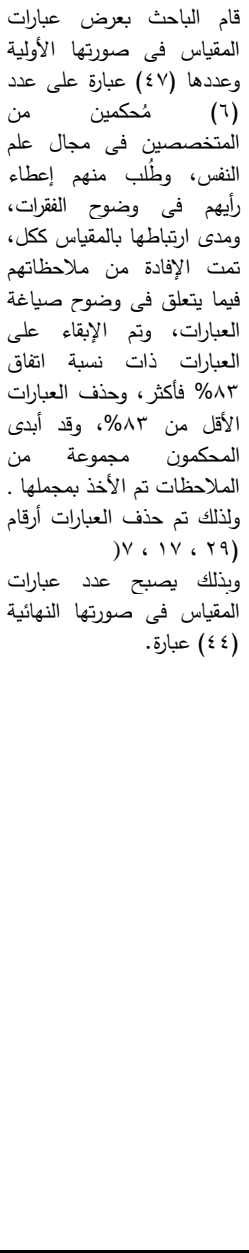 & 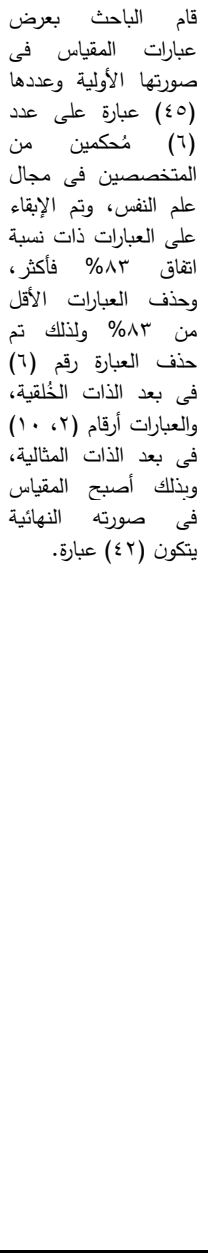 & 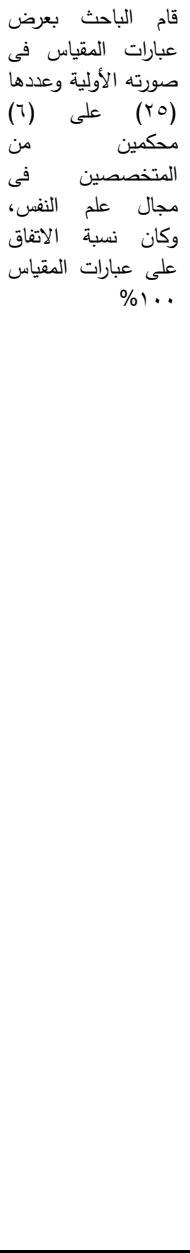 & 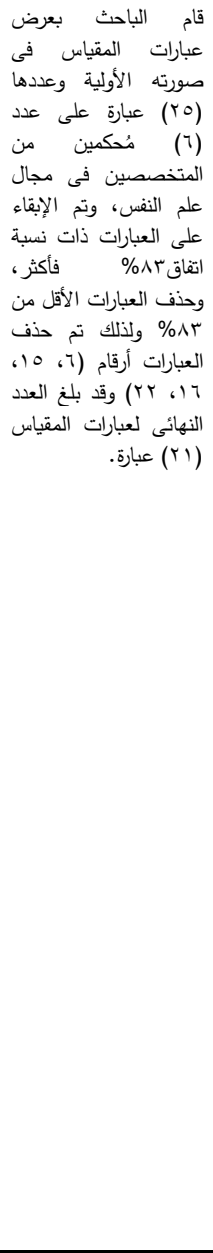 & 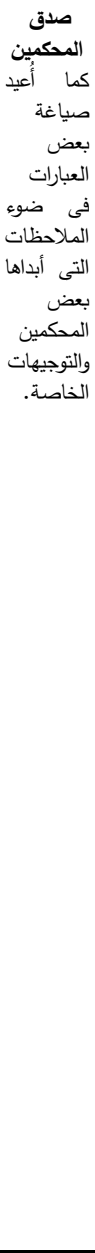 \\
\hline تمع تطيبق الاسقياسر بالألزامن. & تقياس تطبيق المقياس بالتزلزامن مع & تالتمامن تطبيق مع مقيشياس & تالتزم تطبيق مق مقياسياس & تالضبط تطبيق مقاسياس وجهة & التلازمي \\
\hline
\end{tabular}




\begin{tabular}{|c|c|c|c|c|c|}
\hline 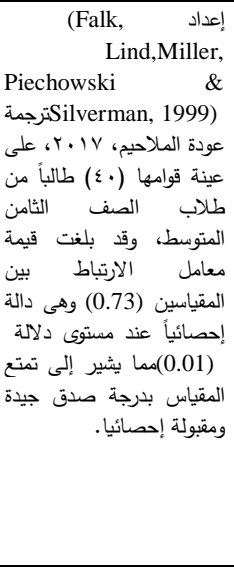 & 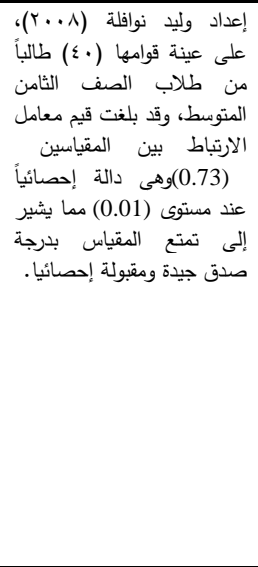 & 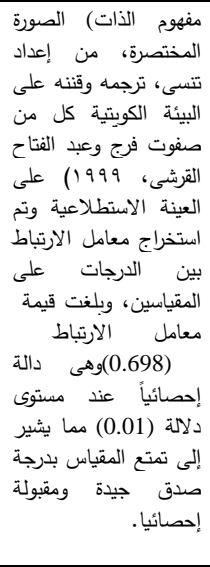 & 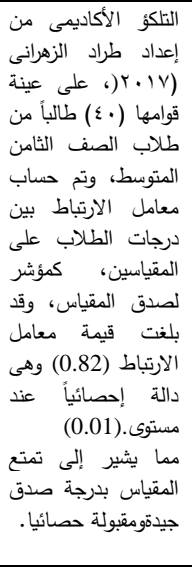 & 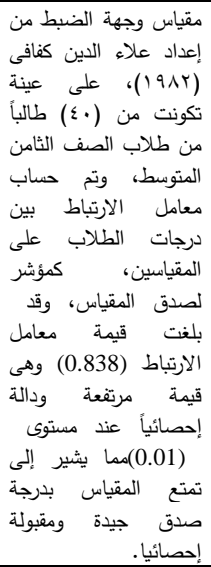 & \\
\hline 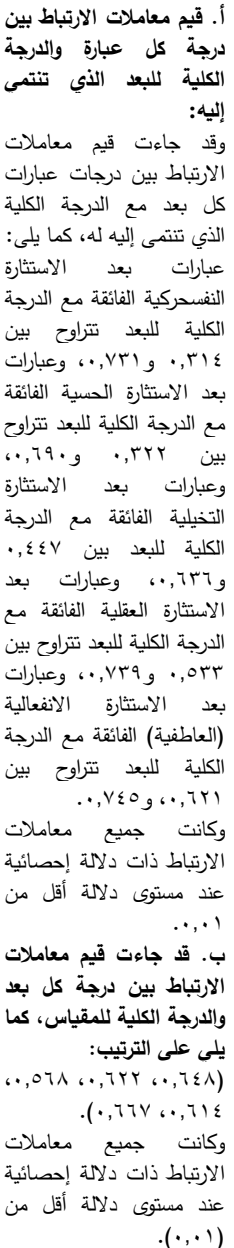 & 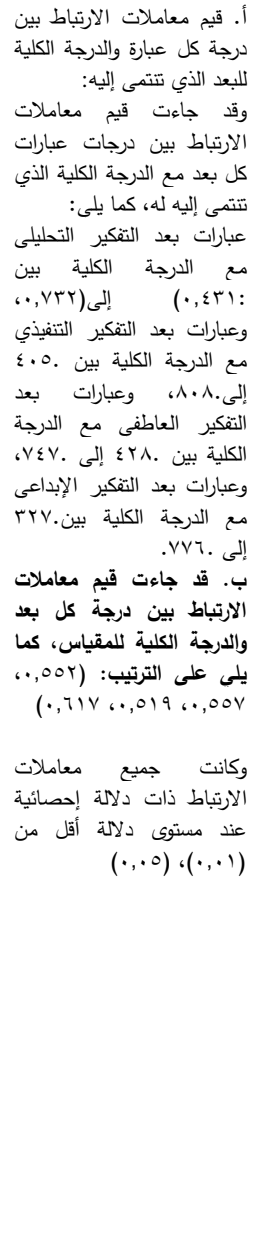 & 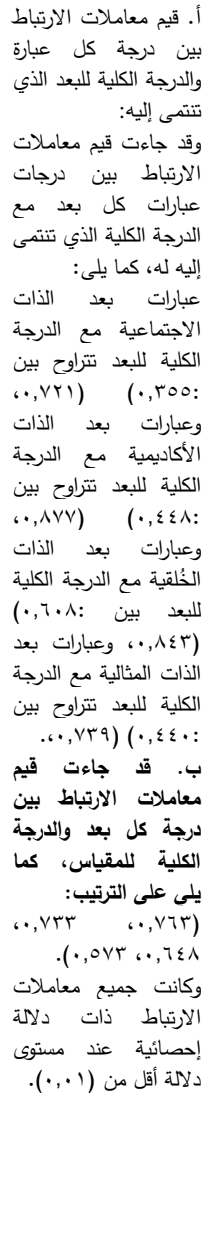 & 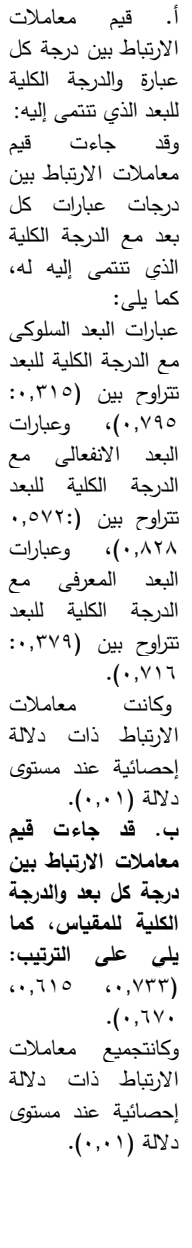 & 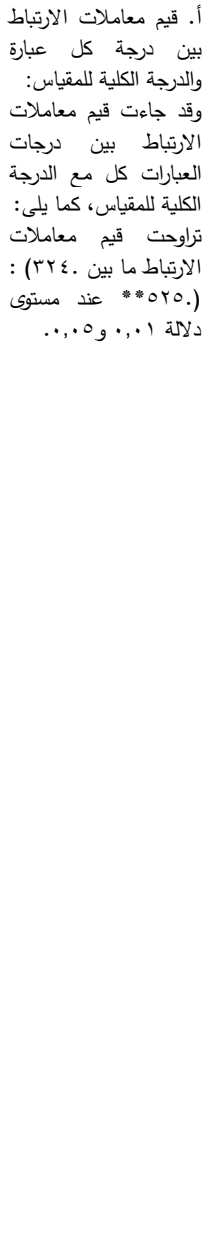 & الالاخلي \\
\hline
\end{tabular}

Y119 


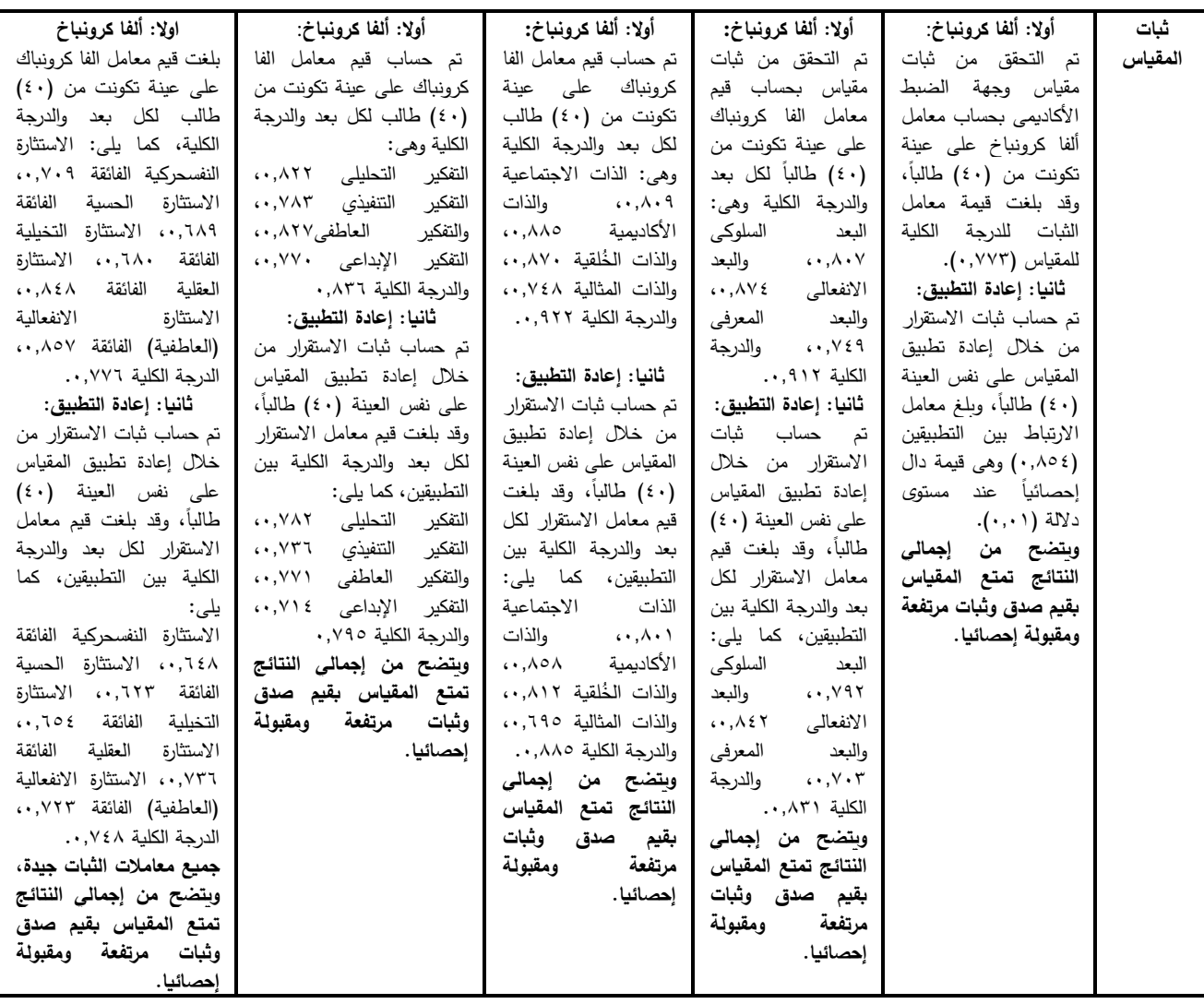

$$
\begin{aligned}
& \text { رابعا: خطوات البحث: يوضح الثكل التالي خطوات البحث: } \\
& \text { 1- خطوات فزز عينة البحث } \\
& \text { • رصد الدرجات على برنامج Spss22 ثم معالجة البيانات في ضوء فروض البحث. } \\
& \text { • مناقثة وتقسير النتائج التي تم الحصول عليها. } \\
& \text { • تقديم توصيات وبحوث مقترحة في ضوء نتائج البحث. } \\
& \text { نتائسج البحث ومناقشتهـا: } \\
& \text { ابتكاريًا وأقرانهخ من الموهوبين العاديين في مفهوم الأات". }
\end{aligned}
$$

اللتحقق من صحة هذا الفرض استخدم الباحث اختبار (t) للعينات المستقلة Independent Test Samples t للكثف عن دلالة الفروق بين متوسطي درجات الموهوبين ابتكاريًا وأقرانهم من الموهوبين العاديين في مفهوم الذات، وجاءت النتائج كما هي موضحة بجدول(؟) على النحو الآتي: 
جدول(r) قيمة "t" للفرق بين متوسطي درجات الموهوبين ابتكاريًا والموهوبين العاديين على مقياس مفهوم الذات

\begin{tabular}{|c|c|c|c|c|c|c|c|}
\hline مستوى الدلالة & df & قيمة "ت" & الانحراف المعياري & المتوسط & العدد & الموهوبون & الأبعاد \\
\hline \multirow{2}{*}{$\cdot,+1$} & \multirow{2}{*}{$v \cdot$} & \multirow{2}{*}{$V, \cdot V Y-$} & $1 Y, V 9 \leq$ & $r, q V$ & די & العاديين & \multirow{2}{*}{ لذات الاجتماعية| } \\
\hline & & & 0, , 0 r & $\leqslant 9,07$ & ry & ابتكاريًا & \\
\hline \multirow{2}{*}{$\cdot,+1$} & \multirow{2}{*}{$v \cdot$} & \multirow{2}{*}{ 7, } & Mr,ATo & M, YA & 4 & العاديين & \multirow{2}{*}{ الذات الأكاديمية | } \\
\hline & & & $\vee, 977$ & $\leqslant 7, \vee 0$ & די & ابتكاريًا & \\
\hline \multirow{2}{*}{$\cdot,+1$} & \multirow{2}{*}{$v \cdot$} & \multirow{2}{*}{$7,7 \leqslant \wedge-$} & $v, 11 \wedge$ & $r \wedge, r \wedge$ & 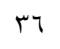 & العاديين & \multirow{2}{*}{ الذات الخلقية } \\
\hline & & & $1, Y)$. & $r 7, Y \wedge$ & די & ابتكاريًا & \\
\hline \multirow{2}{*}{$\cdot, \cdot 1$} & \multirow{2}{*}{$v \cdot$} & \multirow{2}{*}{$V, I Y r-$} & $1 Y, 010$ & $r 9,79$ & די & العاديين & \multirow{2}{*}{ الذات المثالية } \\
\hline & & & $r, \wedge \wedge \vee$ & $\leqslant 0, Y_{0}$ & דיז & ابتكاريًا & \\
\hline \multirow{2}{*}{$\cdot, \cdot 1$} & \multirow{2}{*}{$v \cdot$} & \multirow{2}{*}{$7,9 \wedge \wedge-$} & $\varepsilon \varepsilon, r Y q$ & ITY,YT & 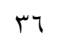 & العاديين & \multirow{2}{*}{ الدرجة الكلية } \\
\hline & & & $V, V \leq 0$ & $I V V, \wedge T$ & דו & ابتكاريًا & \\
\hline
\end{tabular}

توجد فروق ذات دلالة إحصائية بين متوسطي درجات الموهوبين ابتكاريًا والموهوبين العاديين على بعد الـذات الاجتماعيـة كأحد أبعاد مقياس مفهوم الذات لصـالح الموهـوبين ابتكاريًا

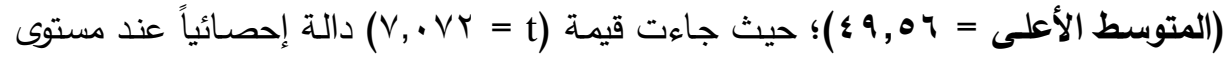

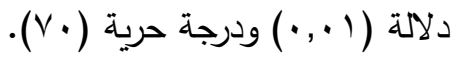
• توجد فروق ذات دلالة إحصائية بين متوسطي درجات الموهوبين ابتكاريًا والموهوبين العاديين

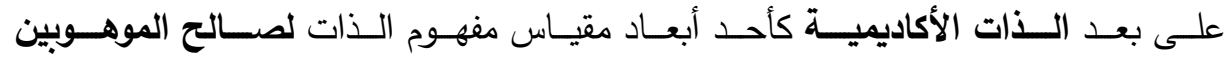

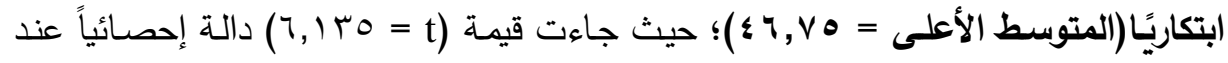

$$
\text { مستوى دلالة ( ( , ·•) ودرجة حرية (•V). }
$$
• توجد فروق ذات دلالة إحصائية بين متوسطي درجات الموهوبين ابتكاريًا والموهوبين العاديين على بعد الذات الخلقية كأحد أبعاد مقياس مفهوم الذات لصالح الموهوبين ابتكاريًا (المتوسط دهوبن

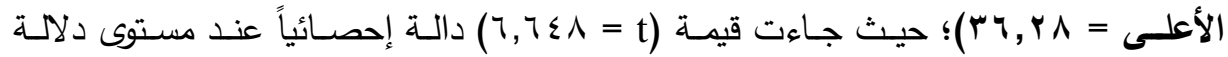

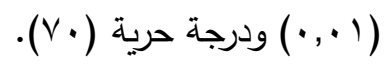
• توجد فروق ذات دلالة إحصائية بين متوسطي درجات الموهوبين ابتكاريًا والموهوبين العاديين على بعد الذات المثالية كأحد أبعاد مقياس مفهوم الذات لصالح الموهوبين ابتكاريًا (المتوسط لونين 


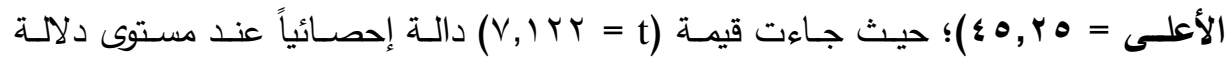

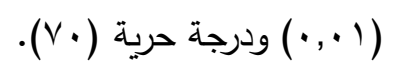

• توجد فروق ذات دلالة إحصائية بين متوسطي درجات الموهوبين ابتكاريًا والموهوبين العاديين

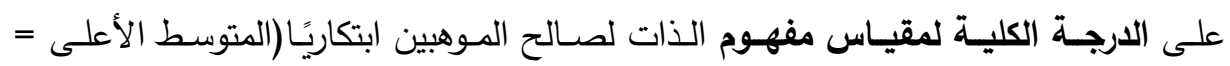

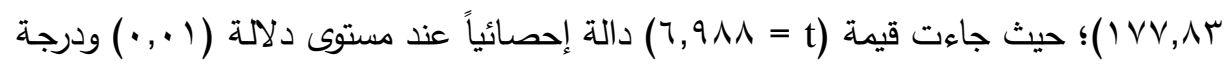

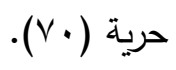

يرى الباحث أن بروز سمة مفهوم الذات لصالح الموهوبين ابتكاريا عن أقارنهم الموهوبين

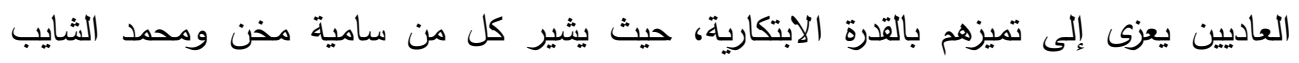

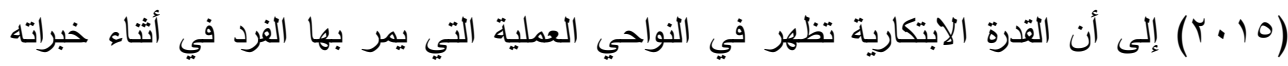
والتي تؤدي إلى تحسين وتتمية ذاته كما أنها تعبر عن فرديته وتقرده وهو ما يحدث نتيجة لتنمية

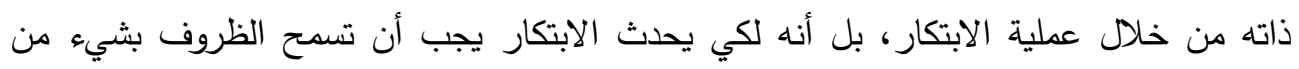

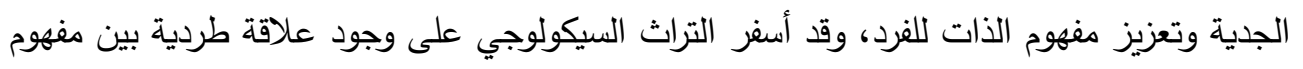

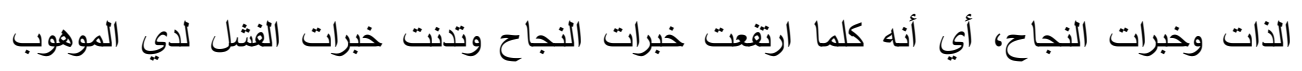
المبتكر أسفر ذلك عن ارتفاع مفهوم الذات لديه، وعلى النقيض فان الطلاب الموهوبين العاديين

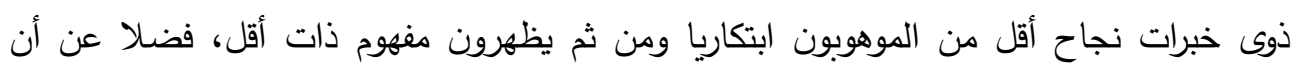

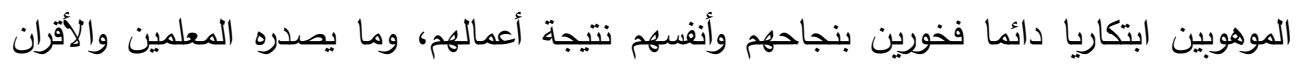

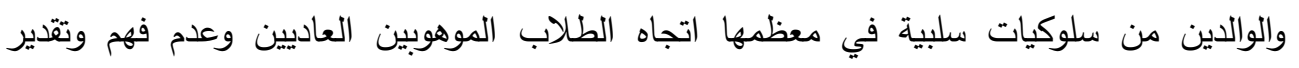
مواهبهم لكونها غير محسوسة في عمل مادي واضح، على النقيض ما يظهرون من سلوكيات

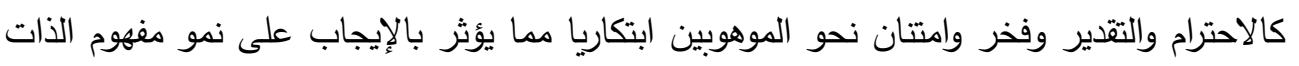

الفرض الثاني: "توجد فروق ذات دلالة إحصائيةً بين متوسطي درجات الموهوبين ابتكاريًا

$$
\text { وأقرانهم من الموهوبين العاديين في أساليب التفكير". }
$$

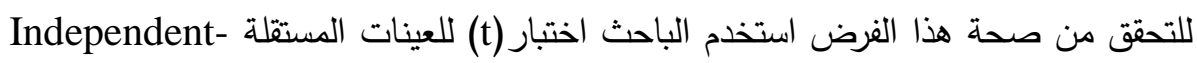
Samples t - Test

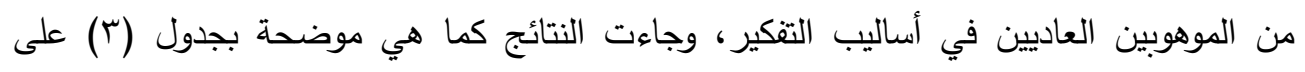

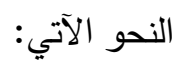


جدول (ץ) قيمة "t" للفرق بين متوسطي درجات الموهوبين ابتكاريًا والموهوبين العاديين على مقياس أساليب التفكير

\begin{tabular}{|c|c|c|c|c|c|c|c|}
\hline مستوى الدلالة & df & قيمة "ت" & الانحراف المعياري & |المتوسط | & | العدد & الموهوبون & الأبعاد \\
\hline \multirow{2}{*}{$\begin{array}{c}0.345 \\
\text { غير دالة }\end{array}$} & \multirow{2}{*}{$v$. } & \multirow{2}{*}{., 90} & 7,817 & $r \wedge, \cdot r$ & $r 4$ & العاديين & \multirow{2}{*}{ التفكير التحليلي } \\
\hline & & & $7,97 V$ & rq,Or & ry & ابتكاريًا & \\
\hline \multirow{2}{*}{ غير دالة } & \multirow{2}{*}{$v \cdot$} & \multirow{2}{*}{$\cdot, r \leq \leq$} & $\leq, 99 \leq$ & $r \leqslant, 04$ & r & العاديين & \multirow{2}{*}{ التفكير التتفيذي } \\
\hline & & & ט & $r \leqslant, r_{0}$ & r & ابتكاريًا & \\
\hline \multirow{2}{*}{$\begin{array}{c}0.666 \\
\text { غير دالة }\end{array}$} & \multirow{2}{*}{$v \cdot$} & \multirow{2}{*}{$\cdot, \varepsilon r r$} & $\neg, \ldots v$ & $\varepsilon \cdot, 04$ & ry & العاديين & \multirow{2}{*}{ التفكير العاطفي } \\
\hline & & & $0,90 \mathrm{~V}$ & $r q, q \leq$ & $m 4$ & ابتكاريًا & \\
\hline \multirow{2}{*}{ غير دالة } & \multirow{2}{*}{$v \cdot$} & \multirow{2}{*}{$\cdot, \leqslant 10$} & $\varepsilon, T \vee 0$ & MY,Or & ry & العاديين & \multirow{2}{*}{ تتفكير الإبداعي } \\
\hline & & & $\varepsilon, \varepsilon \backslash V$ & $r q, \cdot \Lambda$ & $r 4$ & ابتكاريًا & \\
\hline \multirow{2}{*}{$\begin{array}{c}0.556 \\
\text { غير دالة }\end{array}$} & \multirow{2}{*}{$v \cdot$} & \multirow{2}{*}{$\cdot, 09 Y$} & $19, \vee 11$ & $1 \leqslant 9,7 v$ & rq & العاديين & \multirow{2}{*}{ الدرجة الكلية } \\
\hline & & & ru, rVr & $1 \leqslant 4, \wedge 1$ & rq & ابتكاريًا & \\
\hline
\end{tabular}

يتضح من نتائج جدول (ץ) الآتي:

• لا توجد فروق ذات دلالــة إحصـائية بـين متوسطي درجـات الموهوبين ابتكاريًا والموهوبين

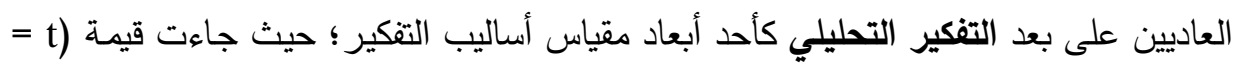

ه 90

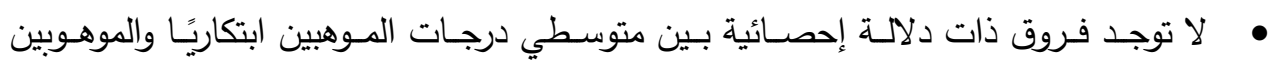

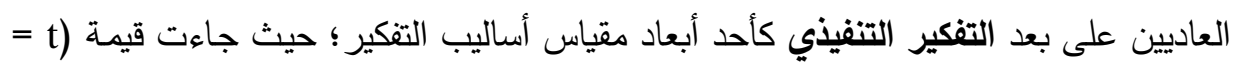

ع

• لا توجد فروق ذات دلالــة إحصـائية بين متوسطي درجـات الموهوبين ابتكاريًا والموهوبين

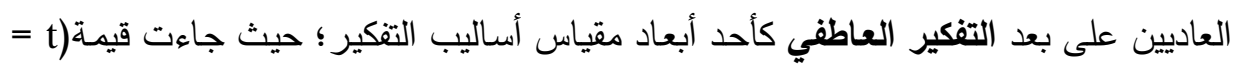

س بـ , •) غير دالة إحصائياً.

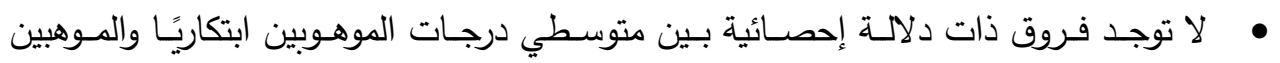

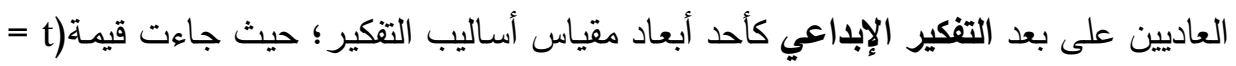

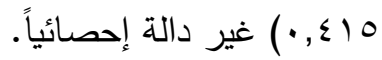


• لا توجد فـروق ذات دلالــة إحصـائية بـين متوسطي درجـات الموهوبين ابتكاريًا والموهوبين

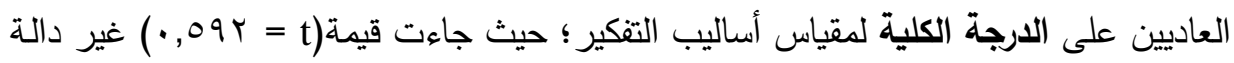
إحصائياً.

يتضح من نتائج الفرض الثاني أنه لا توجد فروق ذات دلالة إحصائية بين متوسطي درجات

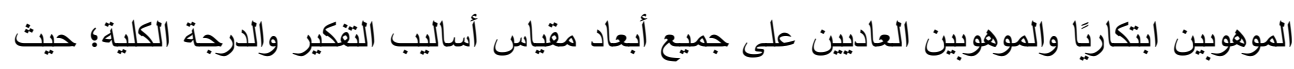

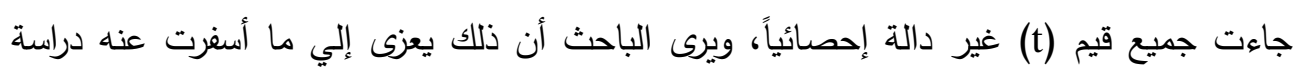

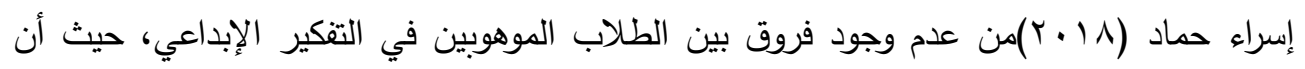

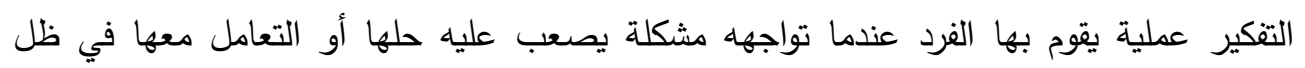
ترسباته الزمنية ومعرفته السابقة فيلجأ إلى النشاط الفكري ليصل إلى بلورة حل لهذه الهُه المشكلة، ودائما

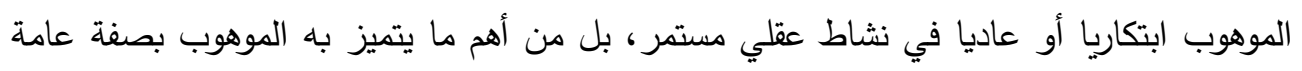

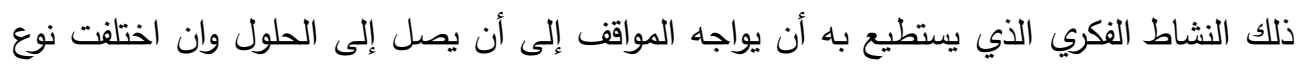

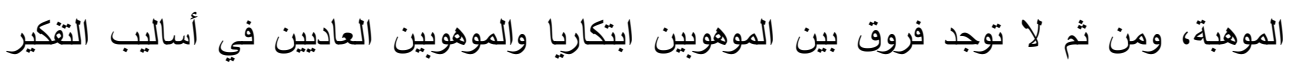
المعبرة عن ديمومة النشاط العقلي لدي الموهوب بصفة توفي عامة.

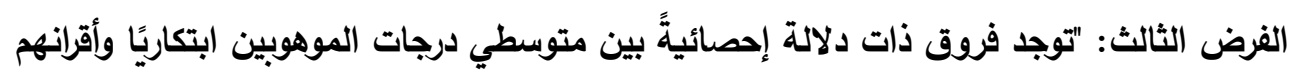
من الموهوبين العاديين في وجهة الضبط الأكاديمية".

جدول (؛) قيمة "t" للفرق بين متوسطي درجات الموهوبين ابتكاريًا والموهوبين العاديين على

\begin{tabular}{|c|c|c|c|c|c|c|c|}
\hline \multicolumn{8}{|c|}{ مقياس وجهة الضبط } \\
\hline | مستوى الدلالة & df & قيمة "ت" & | الانحراف المعياري & المتوسط & العدد & الموهوبون & الأبعاد \\
\hline \multirow{2}{*}{$\cdot, \cdot 1$} & \multirow{2}{*}{ v. } & \multirow{2}{*}{$1 ., 119$} & $\{, 101$ & $11, V Y$ & rq & العاديين & \multirow{2}{*}{ درجة الكليا } \\
\hline & & & $1,\{01$ & ו ו & rq & ابتكاريًا & \\
\hline
\end{tabular}

يتضح من نتائج جدول (؛) أنه توجد فروق ذات دلالة إحصائية بين متوسطي درجات

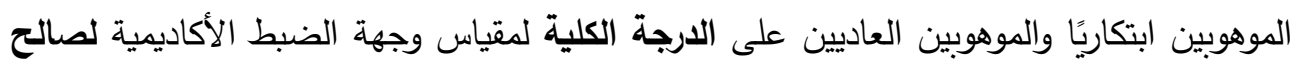

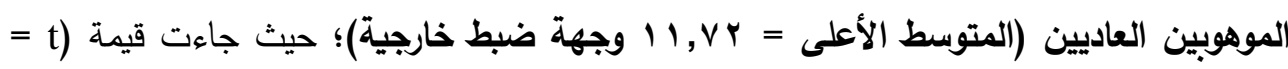

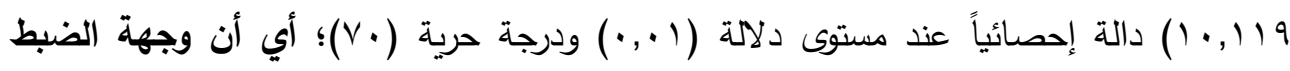


الأكاديمية لاى الموهوبين العاديين خارجية، بينما وجهة الضبط الأكاديمية لاى الموهوبين ابتكاريًا

داخلية.

يرى الباحث بناءً على ما أشار إليه التراث السيكولوجي في تفسير وجهة الضبط بأنها تعبر

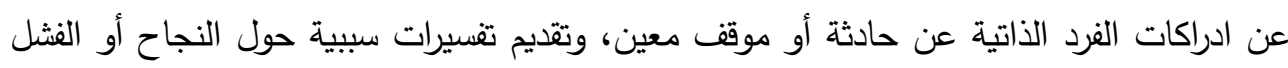

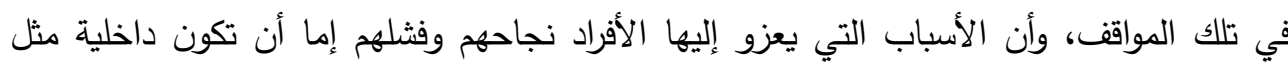
القدرة، والجهد، أو خارجية مثل الحظ، وصعوبة المهمة، وفى هذا الصدد يثير جوجار وإيجاز (Aijaz, 2014 \& Gujjar) مصادر داخلية يمكن السيطرة عليها مثل: الجها الذي يبذله الطالب، أو استخدام الطلاب استراتيجيات مناسبة، هم أكثر تميز وقدرة على مواجهة الصعوبات، في حين أن الطلاب الذين

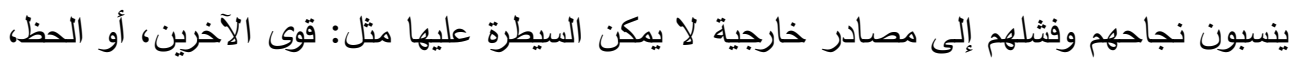
أو الصدفة هم أقل تميز وأكثر عرضة للانسحاب عندما يواجهون أية صعوبات، ويرى بأن نتيجة

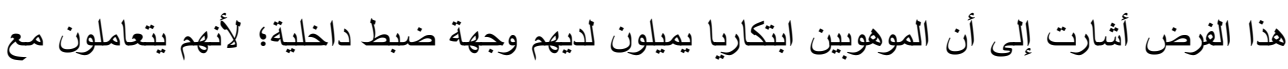

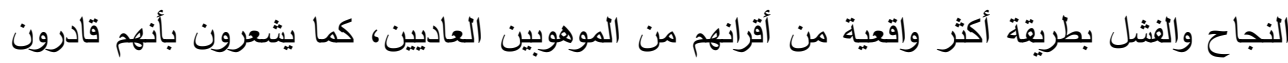

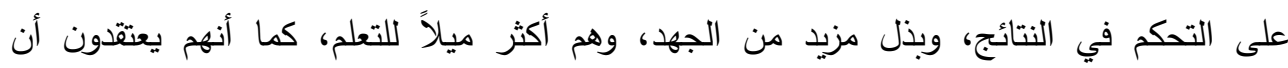

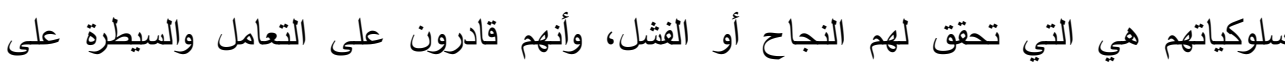
تعزيزاتهم، مما يؤثر في جهودهم نحو النجاح، بينما يظهر الموهوبين العاديين الذين وجهة ضبط

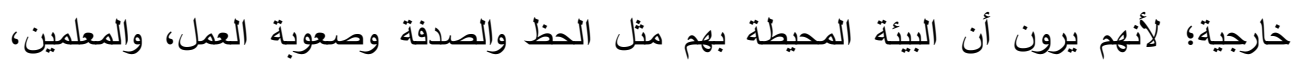
والأقران، والأسرة، هي التي تأثر على نجاحهم أو فثلهم، وقد يرجع ذلك التفاعل السلبي بين تلك الكئك السلوكيات وبعض خصائص الموهوبين التي تتمثل في الحساسية المفرطة وقوة العاطفة والكمالية والثعور بالاختلاف عن الآخرين، مما يجعلهم أكثر عرضه عن ذويهم إلى كثير من المشكلات

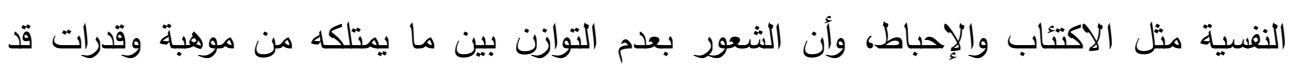
تعرضه للمجازفة والمخاطرة في كثير من المواقف، ويعاني من جلد الذات والمحاسبة المفرطة

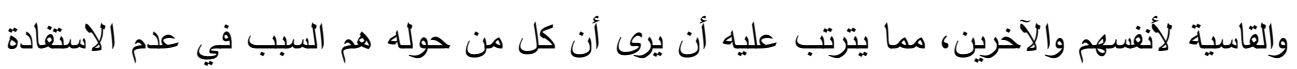

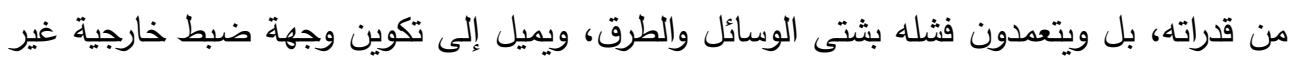

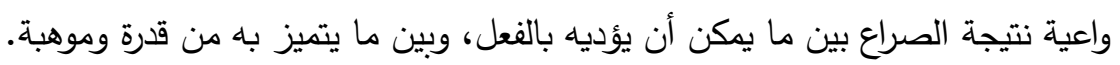
الفرض الرابع: "توجد فروق ذات دلالة إحصائيةً بين متوسطي درجات الموهوبين ابتكاريًا وأقرانهم من الموهوبين العاديين في التلكؤ الأكاديمي". 
جدول (ه) قيمة "t" للفرق بين متوسطي درجات الموهوبين ابتكاريًا والموهوبين العاديين على مقياس التلكؤ الأكاديمي

\begin{tabular}{|c|c|c|c|c|c|c|c|}
\hline مستوى الدلالة & df & "t" قيمة & الانحراف المعياري & المتوسط & العدد & الموهوبون & الأبعاد \\
\hline \multirow{2}{*}{$\cdot,+1$} & \multirow{2}{*}{$v$. } & \multirow{2}{*}{$0, Y 01$} & $1 \leq, 0 r r$ & $r q, \wedge)$ & צ' & العاديين & \multirow{2}{*}{ البعد السلوكي } \\
\hline & & & $\varepsilon, 1 \vee$. & 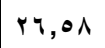 & q & ابتكاريًا & \\
\hline \multirow{2}{*}{., .1} & \multirow{2}{*}{$v$. } & \multirow{2}{*}{$7, \vee>0$} & 7,911 & Yo,o. & צ' & العاديين & \multirow{2}{*}{ لبعد الانفعالي. } \\
\hline & & & $1,0 \vee v$ & $1 v, 0$. & צ' & ابتكاريًا & \\
\hline \multirow{2}{*}{$\cdot,+1$} & \multirow{2}{*}{ V. } & \multirow{2}{*}{$\checkmark, \wedge \wedge \bullet$} & $\nearrow,\{0 ૫$ & $\bullet 9, \cdot 1$ & ry & العاديين & \multirow{2}{*}{ لبعد المعرفي } \\
\hline & & & $r, q r v$ & $0,9 \leq$ & צ' & ابتكاريًا & \\
\hline \multirow{2}{*}{., .1} & \multirow{2}{*}{ v. } & \multirow{2}{*}{ צ Y, Y } & Y & $I r \varepsilon, r q$ & r & العاديين & \multirow{2}{*}{ الدرجة الكلية } \\
\hline & & & $\vee, \leqslant \wedge I$ & $90, \cdot r$ & צ' & ابتكاريًا & \\
\hline
\end{tabular}

يتضح من نتائج جدول(0) الآتي:

• توجد فروق ذات دلالة إحصائية بين متوسطي درجات الموهوبين ابتكاريًا والموهوبين العاديين

على البعد السلوكي كأحد أبعاد مقياس التلكؤ الأكاديمي لصالح الموهوبين العاديين (المتوسط

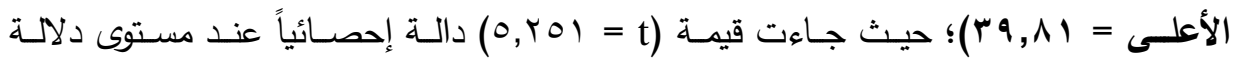

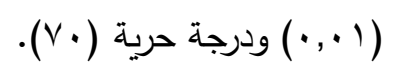

• توجد فروق ذات دلالة إحصائية بين متوسطي درجات الموهوبين ابتكاريًا والموهوبين العاديين

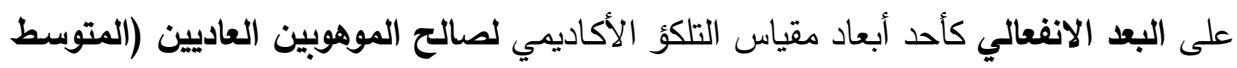

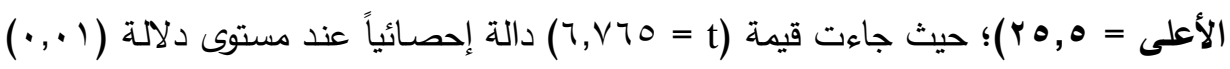

$$
\text { ودرجة حرية (V•) (V) }
$$

• توجد فروق ذات دلالة إحصائية بين متوسطي درجات الموهوبين ابتكاريًا والموهوبين العاديين على البعد المعرفي كأحد أبعاد مقياس التلكؤ الأكاديمي لصالح الموهوبين العاديين (المتوسط

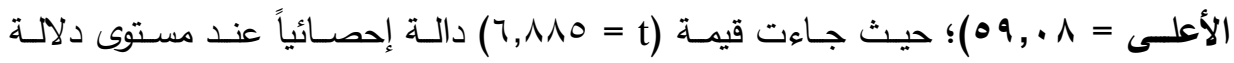

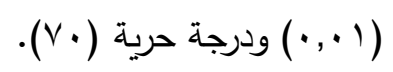

• توجد فروق ذات دلالة إحصائية بين متوسطي درجات الموهوبين ابتكاريًا والموهوبين العاديين

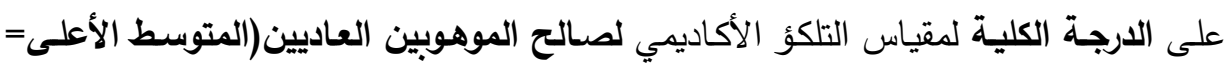




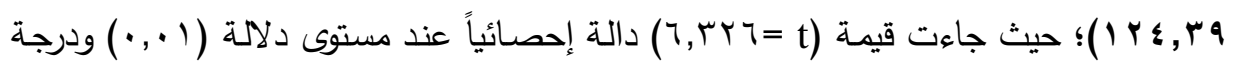

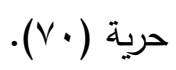

يري الباحث في ضوء ما أشار إليه معاوية أبو غزال(Y) (Y)، أن من أسباب التلكؤ

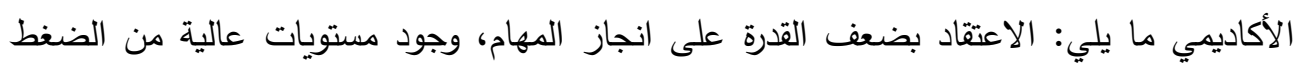

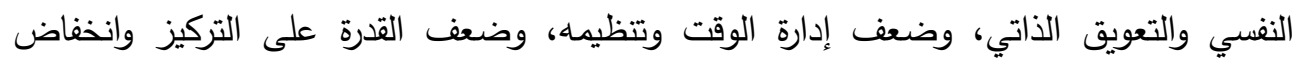
اليقظة العقلية، والخوف والقلق من الفشل، أن تلك الأسباب تتجلى لدى الموهوبين العاديين حيث وضئ إنى يعتقد الموهوب أنه يمتلك قدرات أعلى من المهام المقدمة له، ويشعر بعدم جدوى تلك المهام، أنهاب أنها

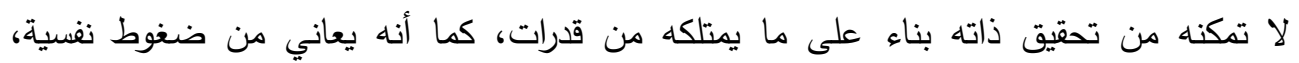

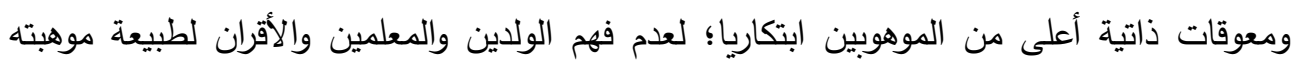

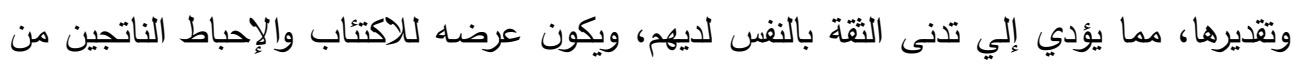

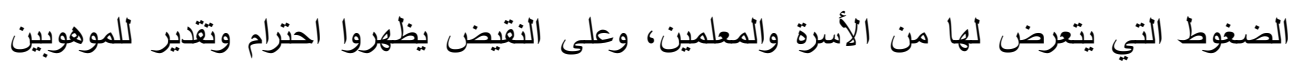

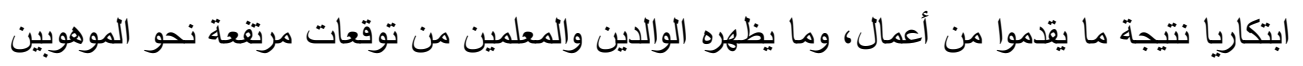

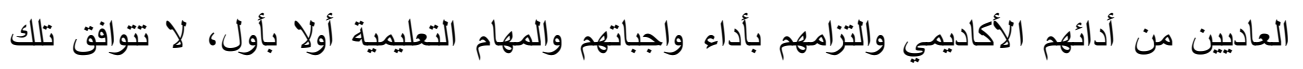
التوقعات مع النتائج الفعلية التي يظهرها الموهوبين العاديين، بل تمثل قيود ومعوقات تؤثر عليه

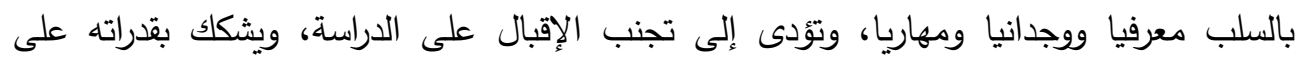
مواجهة المهام التعليمية؛ لأنه يعتقد أنها تثكل تهديدا لذاته، وعدم استخدام المعلمين لأساليب التعليم

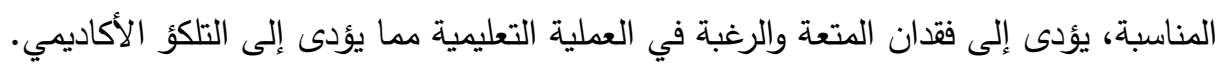

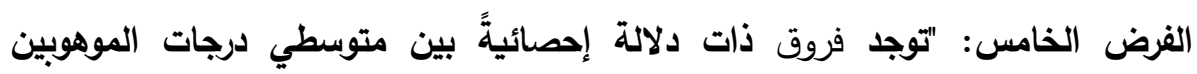
ابتكاريًا وأقرانهم من الموهوبين العاديين في الاستثارة الفائقة". جدول (7) قيمة "t" للفرق بين متوسطي درجات الموهوبين ابتكاريًا والموهوبين العاديين على العادين مقياس الاستثارة الفائقة

\begin{tabular}{|c|c|c|c|c|c|c|c|}
\hline مستوى الدلالة & df & قيمة "t" & الانحراف المعياري & المتوسط & العدد & الموهوبون & الأبعاد \\
\hline \multirow{2}{*}{$\cdot,+1$} & \multirow{2}{*}{ v. } & \multirow{2}{*}{$r, v \leq 1$} & r,rrr & $Y \wedge, 1 \leq$ & ז & العاديين & \multirow{2}{*}{ لاستثارة النفسحركية الفائقة } \\
\hline & & & $1, \leqslant 1$. & $r \bullet, \wedge q$ & rq & ابتكاريًا & \\
\hline \multirow{2}{*}{$\begin{array}{c}0.371 \\
\text { غير دالة }\end{array}$} & \multirow{2}{*}{ v. } & \multirow{2}{*}{$\cdot, 9 \cdot 1$} & r,orr & rq, vo & ז & العاديين & \multirow{2}{*}{ الاستثارة الحسية الفائقة } \\
\hline & & & $r, v q 1$ & $r \wedge, q \vee$ & rq & ابتكاريًا & \\
\hline 0.969 & v. & •, , rq- & $r,|r|$ & $r q, 1 v$ & rq & العاديين & الاستثارة التخيلية الفائقة \\
\hline
\end{tabular}




\begin{tabular}{|c|c|c|c|c|c|c|c|}
\hline غير دالة & & & 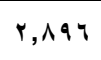 & $r 9,19$ & ч & ابتكاريًا & \\
\hline \multirow{2}{*}{ غير دالة } & \multirow{2}{*}{$v \cdot$} & \multirow{2}{*}{. , TVY } & $r, .97$ & 4,11 & rq & العاديين & \multirow{2}{*}{ الاستثارة العقلية الفائقة } \\
\hline & & & r,rin & $r \cdot, r)$ & rq & ابتكاريًا & \\
\hline \multirow{2}{*}{ غير دالة } & \multirow{2}{*}{$v \cdot$} & \multirow{2}{*}{$1, \cdot v \leqslant$} & $r, \leqslant Y r$ & $\mathrm{M}_{\mathrm{N}, \mathrm{\wedge}}$ & ז & العاديين & \multirow{2}{*}{ الاستثارة الانفعالية الفائقة } \\
\hline & & & Y, V৭५ & 4,11 & ד & ابتكاريًا & \\
\hline \multirow{2}{*}{$\begin{array}{c}0.072 \\
\text { غير دالة }\end{array}$} & \multirow{2}{*}{$v \cdot$} & \multirow{2}{*}{$1, \wedge r O$} & $9, \wedge 10$ & $1 \leqslant 9,9 \leqslant$ & ז & العاديين & \multirow{2}{*}{ الدرجة الكلية } \\
\hline & & & 9,009 & $1 \leqslant 0, \vee \wedge$ & ч & ابتكاريًا & \\
\hline
\end{tabular}

يتضح من نتائج جدول (†) الآتي:

• توجد فروق ذات دلالة إحصائية بين متوسطي درجات الموهوبين ابتكاريًا والموهوبين العاديين

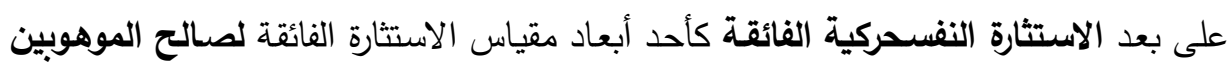

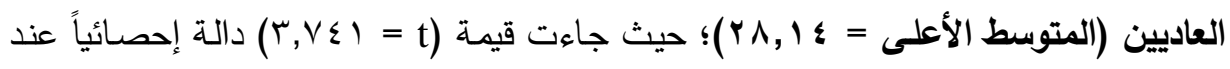

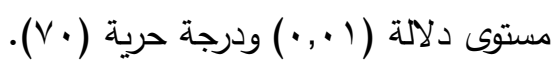

• لا توجد فروق ذات دلالـة إحصـائية بين متوسطي درجـات الموهوبين ابتكاريًا والموهوبين

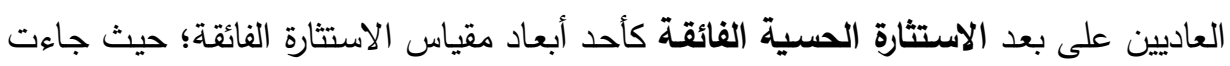

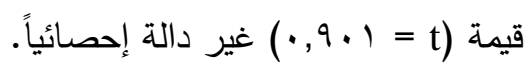

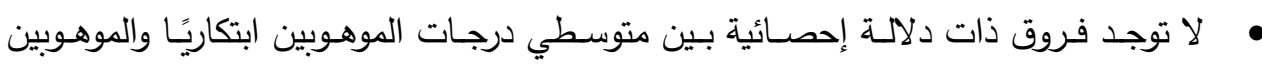

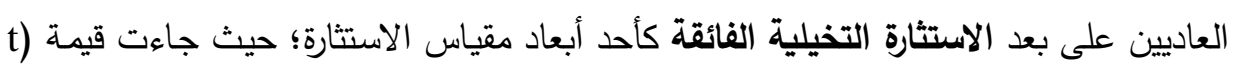

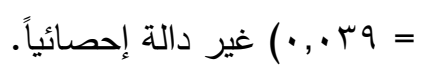

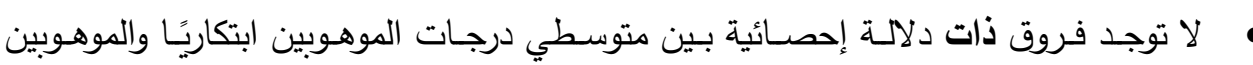

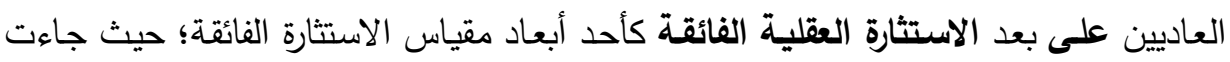

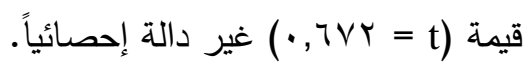

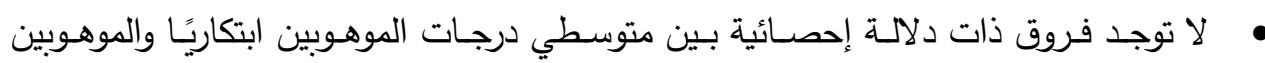

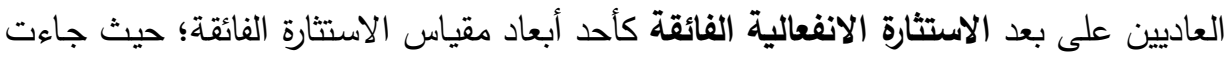

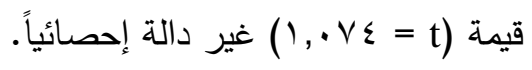

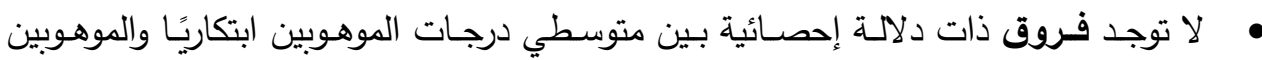

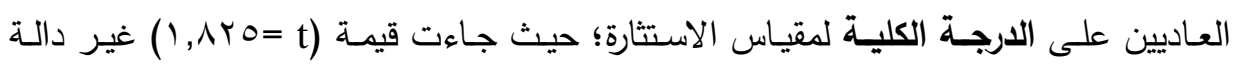
إحصائياً. 
يتضح من نتائج الفرض الخامس انه لا توجد فروق دالة إحصائيا بين الموهوبين ابتكاريا

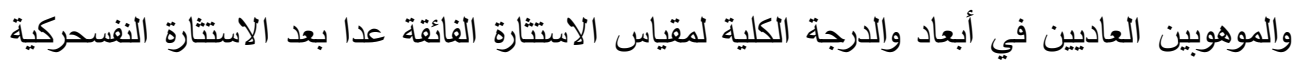
الفائقة لصالح الموهوبين العاديين. يرى الباحث في ضوء ما أشار أحمد زيدان (Y. V V عن صلاحية مقياس الاستثارة النفسية الفائقة في الكثف عن الطلاب ذوي النشاط الإبداعي، حيث أن الاستثارة الفائقة تعبر استجابات

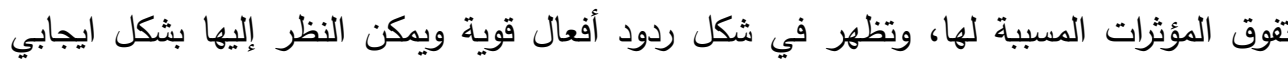

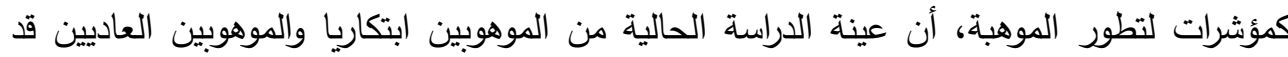
تميزت بخصائص الاستثارة الفائقة كمؤشرات للقدرات والاستعدادات الكامنة الدالة على الموهبة، ومن

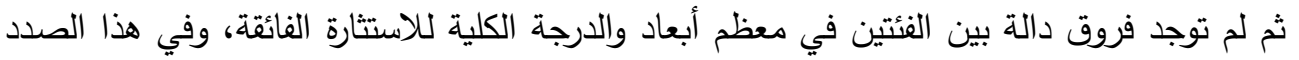

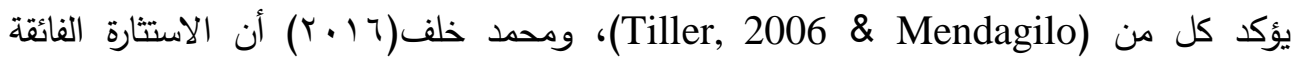
استجابة فوق المتوسط تفوق المؤثرات المسببة لها، وهي استجابة غير متوقعة وغير مخصصة تختلف باختلاف المؤثر، فهي فائض من الطاقة يمكن ملاحظته في كل بعد من الأبعاد المكونة

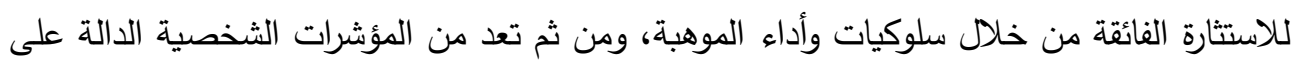

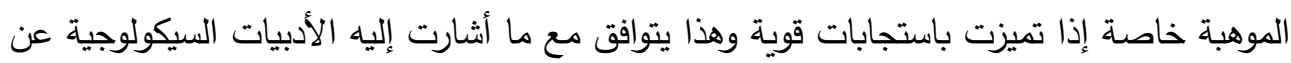
خصائص الموهوبين وتميزهم بالحساسية المفرطة وقوة الملاحظة ورد الفعل المبالغ فيه اتجاه المؤثرات المختلفة، بينما توجد فروق دالة إحصائيا لصالح الموهوبين العاديين في بعد الاستثارة النفسحركية الفائقة التي تعبر عن استثارة مفرطة في الجهاز العضلي العصبي وتظهر في صورة حركة دائمة مستمرة، وتصرف مندفع وسرعة في الكلام والعمل بنثاط نحو التتافس، وتوتر انفعالي يترجم إلى نشاط نفسيحركى كالسلوك الاندفاعي وفرط النشاط، حيث يرجع ذلك إلى تمرد الموهوب

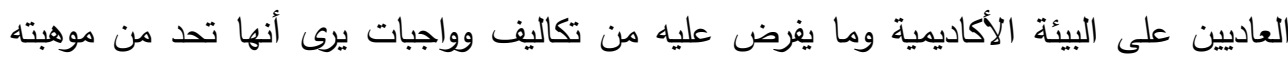

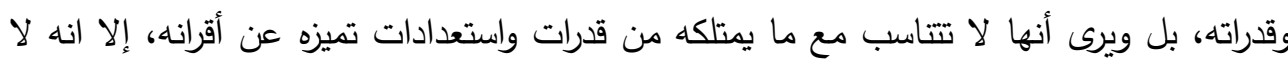

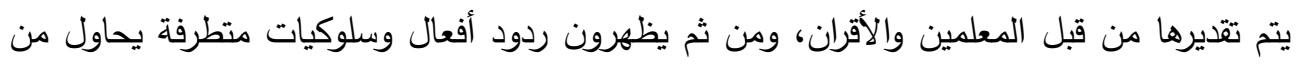

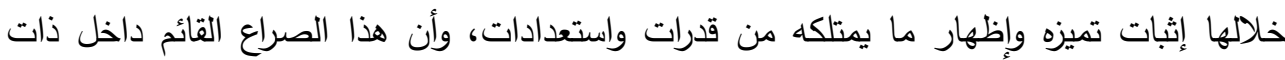
الموهوب بين ما يمتلكه من موهبة تميزه عن غيره وبين عد تفهم نوع موهبته وتقديرها، تجعل ردود

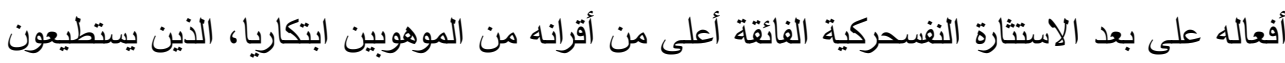

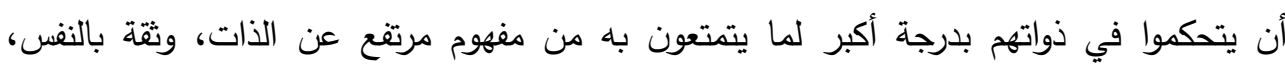


والثبات الانفعالي، حيث لا يتعرضون لذلك الصراع بين ما يمتلكون من موهبة ابتكارية وبين ما يحظون به من تقدير واحترام وإعجاب من الآخرين. التطبيقات التربوية:

في ضوء نتائج البحث يمكن عرض بعض التوصيات والتي تتلخص في:

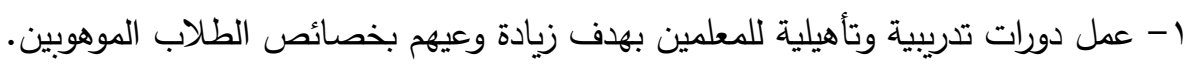

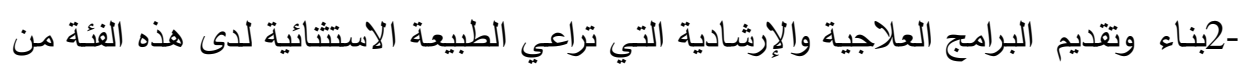
المتعلمين. r- بناء وتطوير الاختبارات والمقاييس الخاصة بفئة الموهوبين وذلك بهدف الكثف الكُبكر عنهم.

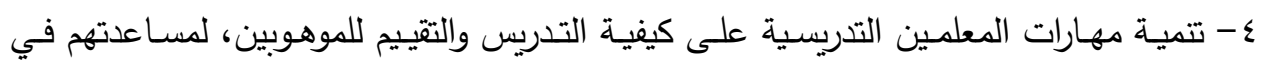

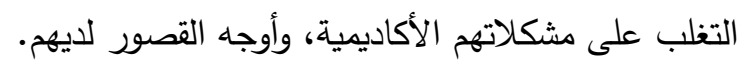
ه- تكثيف الأنشطة والفعاليات المدرسية التي تسهم في تحقيق الاستقرار، والتوافق النفسي لدى لاديه لائه الموهوبين.

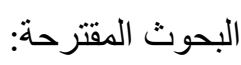

1- فاعلية برنامج إرشادي سلوكي معرفي في خفض مستويات التلكؤ الأكاديمي لدى الموهوبين.

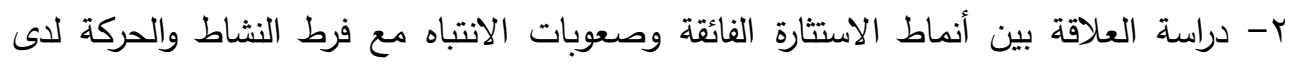
الطلاب الموهوبين عقليا. r- دراسة السمات الثخصية للطلبة الموهوبين الملتحقين بمدارس التمييز والموهوبين في الددارس العادية.

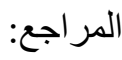

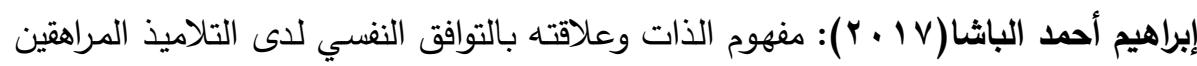

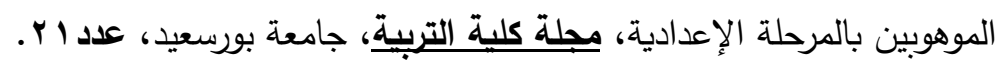

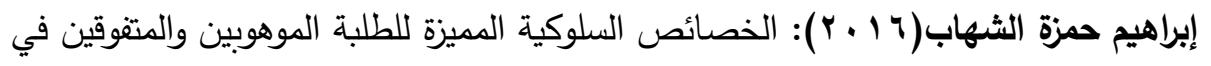

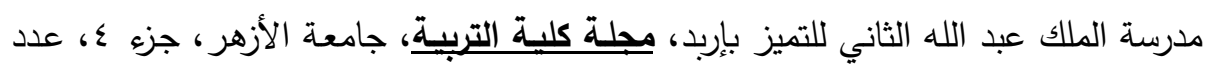

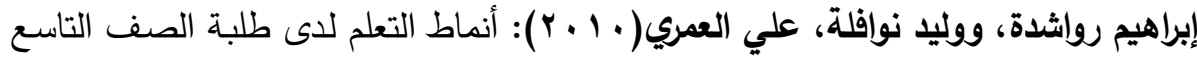

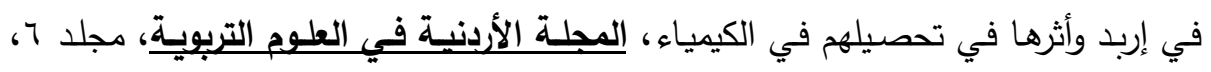




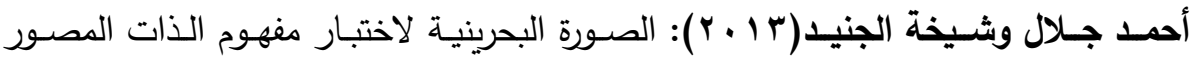

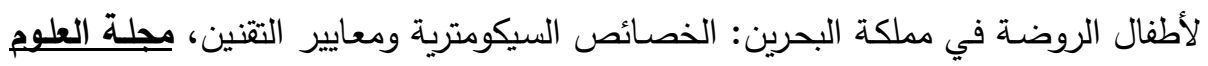

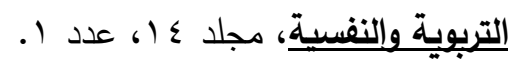

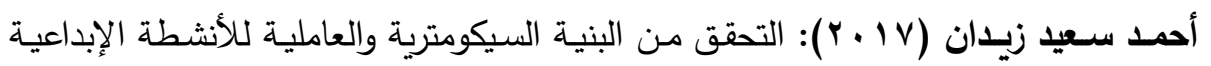

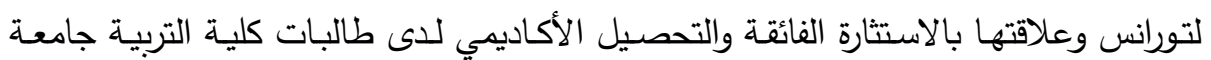

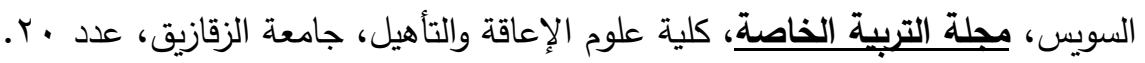

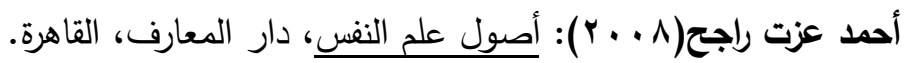

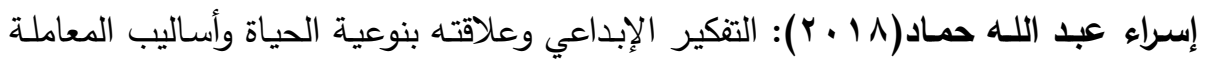

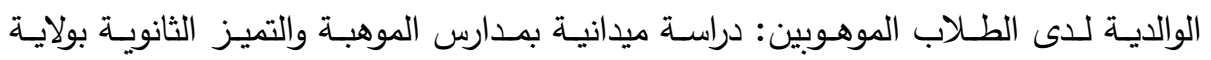
الخرطوم، رسالة ماجستير، كلية الآداب، جامعة أم درمان الإسلامية، السودان.

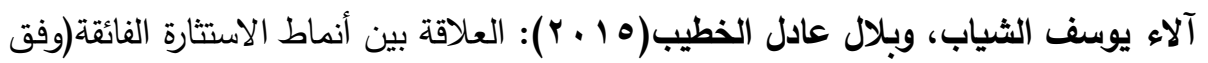
نظرية دابروسكي) وبين التفكير الإبداعي لاى الطلبة الموهوبين والطلبة العاديين في مدارس

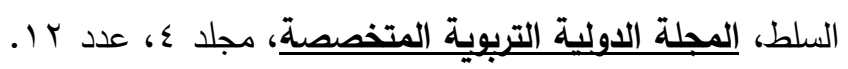

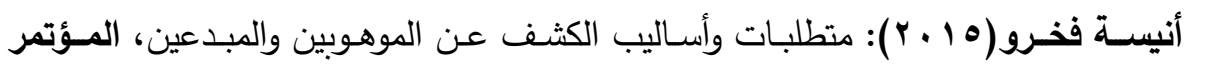
الدولي الثاني للموهوبين والمتفوقين، قسم التربية الخاصـة، كلية التربية، جامعـة الإمـارات العربية المتحدة. ثامر فهـ المطيري( (1 + ؟): نظربـة دابروسكي للكثف عن الموهوبين، دار المسيلة للنشر والتوزيع، الكويت. حجاج غانم علي(Y V V P): التفكير البنائي والابتكاريـة الانفعالية ووجهة الضبط الأكاديمي

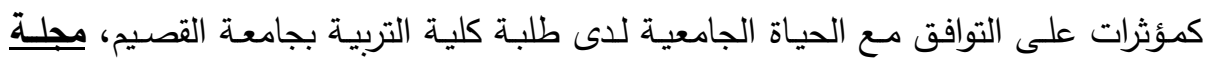

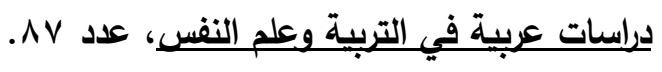
داليا خير الله عبد الهادي(10 ب ب): الفروق بين مرتفعي ومنخفضي التلكؤ الأكاديمي في

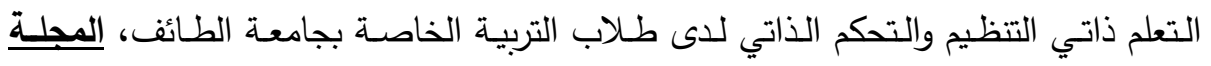

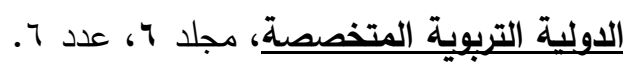

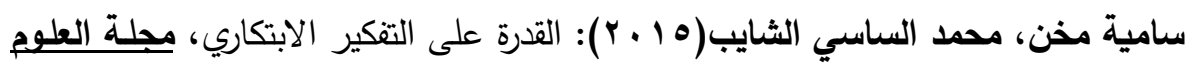

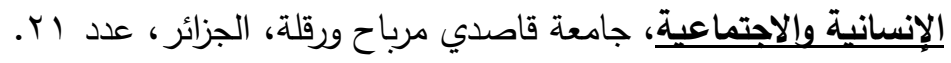
سعود محمد الطواري (1 ا • r): أنماط التفكير، دار المسيلة للنشر والتوزيع، الكويت. 


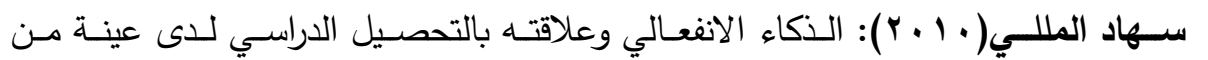

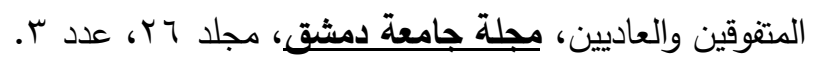

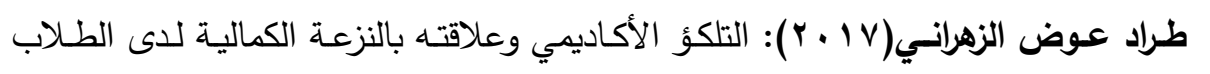

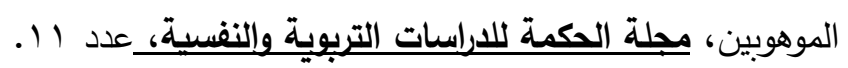

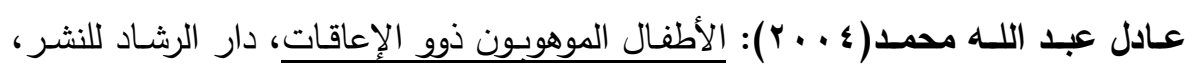
القاهرة.

عبد الرحمن مصلحي، وناديـة الحسيني( ع . ㄷ) : التلكؤ الأكاديمي لدى عينة من طلبة

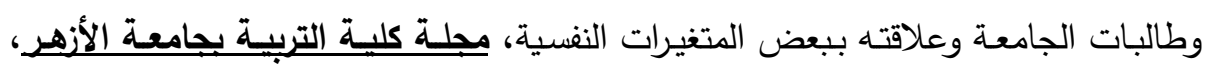
مجلد 1.

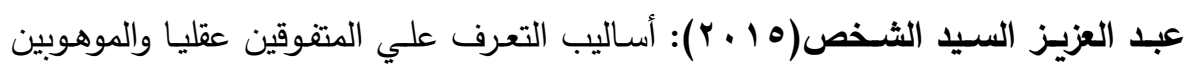
ورعايتهم وتتمية قدراتهم الابتكارية، المؤتمر الدولي الثاني للموهوبين والمتفوقين، قسم التربية الخاصة، كلية التربية، جامعة الإمارات العربية المتحدة.

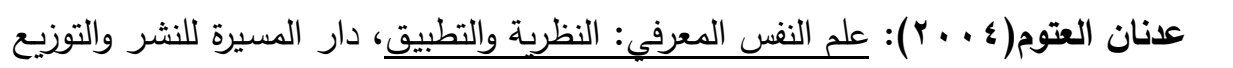
الأردن. عمـاد الزغلـول، وعبد اللـه الصـمادي(0 1 ـ ب):الموهوبون ذوو الاحتياجـات الخاصـة، دار الشروق للنشر والتوزيع، عمان.

علاء الدين كفافي(r 19 1 ): مقياس وجهة الضبط، مكتبة الأنجلو المصرية، القاهرة.

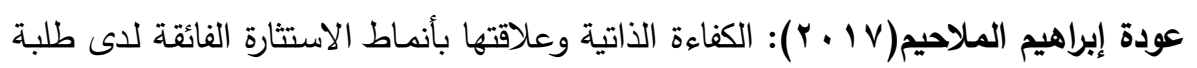

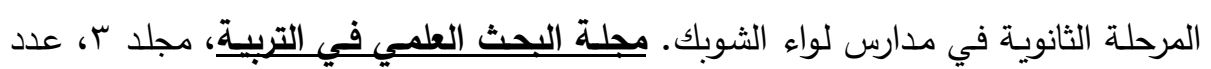

فاطمة أحمد أنو، أحمد محمد شنان(11 ب ـ): الفروق في مركز التحكم ومفهوم الذات بين

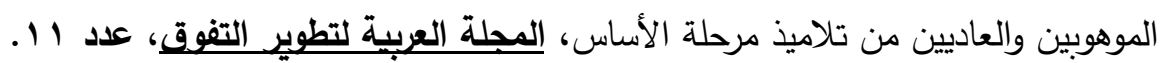

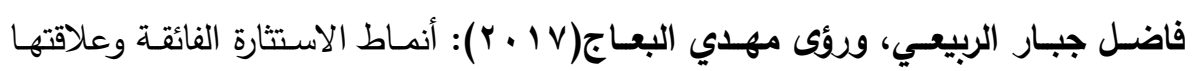

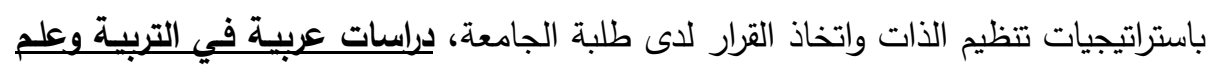

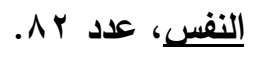

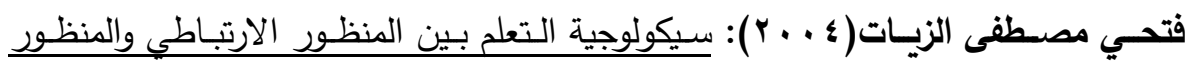
المعرفي، دار النشر للجامعات، القاهرة. 


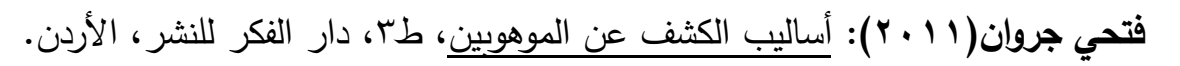

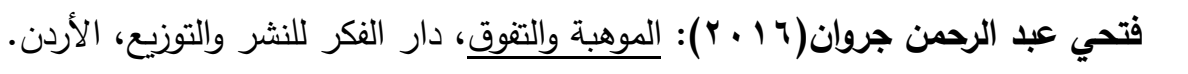

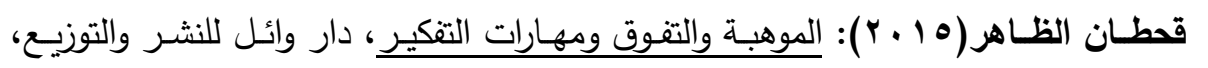
الأردن. محمد شريف خلف(7 1 • r): مستويات الاستثارة الفائقة وعلاقتها بالفاعلية الذاتية الإبداعية

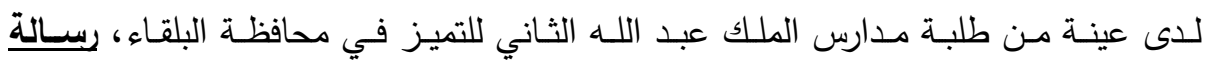
ماجستير، الجامعة الهاشمية، الأردن.

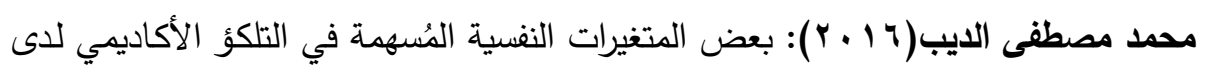

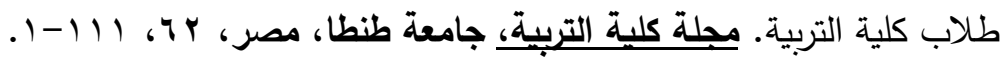

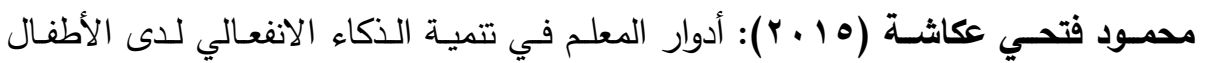

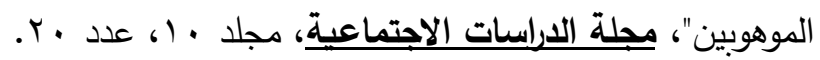

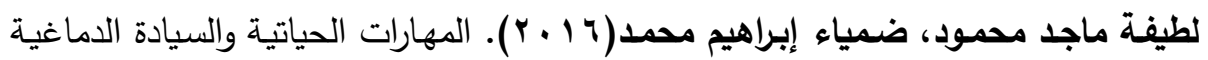

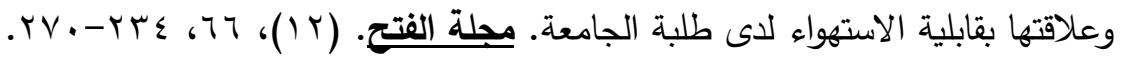

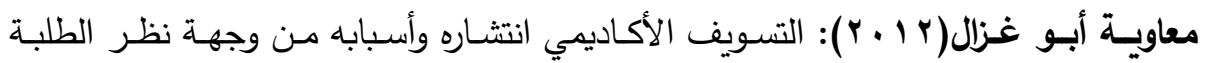

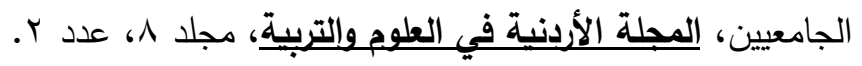

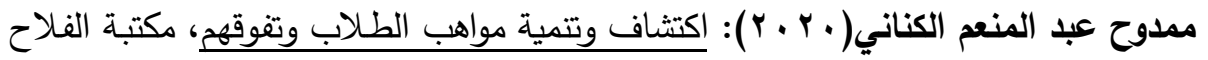

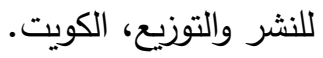

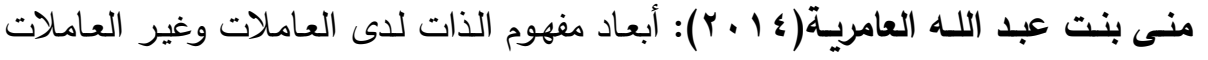

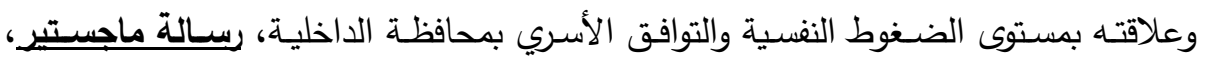
جامعة نزوى، سلطنة عمان هشام مخيمر(9 9 V ( )): وجهة الضبط ومستوى النضج الخلقي لاى الجانحين وغير الجانحين

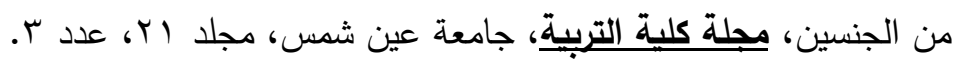
نبيل فضل شرف الدين( ع ץ): مقياس خصائص الموهوبين ذوي صعوبات التعلد، مكتبة الأنجلو المصرية، القاهرة. نجاح عبد الثهيد إبراهيم(ه . . ب): مركز التحكم وعلاقته ببعض عوامل الضغط النفسي لدى تلاميذ المرحلة الإعدادية، مجلة عالم التربية، عدد 17. 


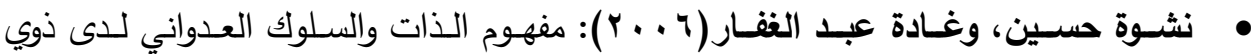

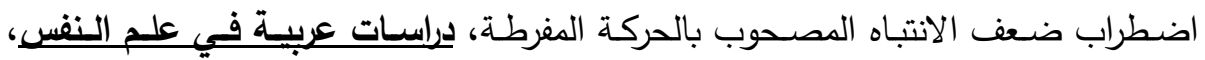

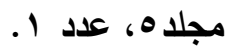

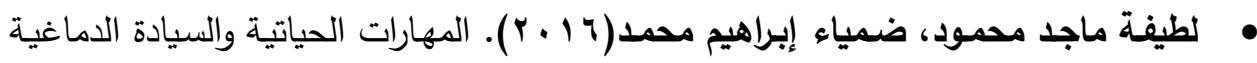

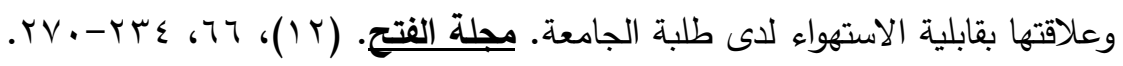

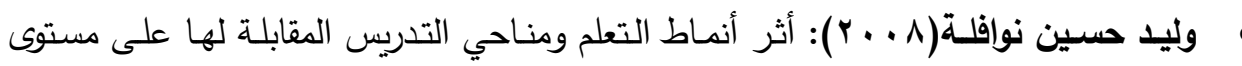

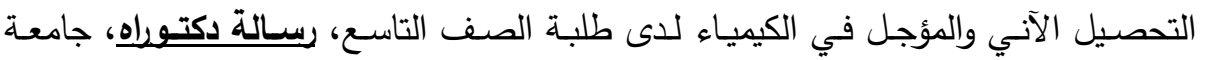

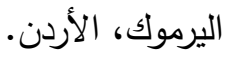

- Anderman, E \& .Jones, S. (2013 :(The fine points of working under pressure :Active and passive procrastination among college students Unpublished Doctoral Thesis .(The Ohio State University, Retrieved from ProQuest Dissertations and Thesis database. (UMI No. 3673155.(

- Connecticut Association for the Gifted(CAG)(2015.(Understanding and challenging the Gifted :A Teacher's Handbook .American Federation of Teachers .Memory, thinking and language: Topics in Cognitive.

- Davis, G. A., \& Rimm, S. B. (2003): Education of the gifted and talented $\left(4^{\text {th }}\right.$ ed.). Needham Heights, MA: Allyn \& Bacon.

- Davis, G. A., \& Rimm, S. B. (2011): Education of the gifted and talented $\left(5^{\text {th }}\right.$ ed.). Boston.

- El-Taha, Ziad. \& AL Sharman, W. (2017). Academic procrastination among gifted and ordinary students and its relationship with some variables. International Journal of Education. 9 (3), 3247.

- Feldman, R. (2011).Understanding psychology. Available from http://www.cee.uma.pt/ron/Greene\%20\%20Memory,\%20thinking\%20 and\%20language.pdf.

- Francis, Preckel; Rach, Hannah; Scherrer, Vesevolod. (2017). Selfconcept changes in multiple self-concept domains of gifted students participating in a summer residential school. International Journal of Gifted and talented. 31(2), 88-101. 
- Gujjar, A. \& Aijaz, R. (2014): A Study to investigate the relationship between locus of control and academic achievement of students. Journal of Educational Psychology, 8(1) p2.

- Heilat, M. (2018): Thinking styles according to Herrmann's brain dominance and their relationship with moral intelligence among gifted students in Jordan. Available at: https://www.researchgate.net/publication/317006606.

- Hodge, K., \& Kemp, C. (2006). Recognition of Giftedness in the Early Years of School: Perspectives of Teachers, Parents, and Children. Journal for the Education of the Gifted, 30(2), 164-204.

- Lekich, N. (2006): The relationship between academic motivation, self-esteem, and academic procrastination in college students(Unpublished Master thesis). Truman State University, Retrieved from ProQuest Dissertations and Thesis database. (UMI No. 1437751).

- Mccloskey, J. \& Shannon, S.(2015): The development and validation of The Academic Procrastination Scale. Research Gate. https://www.research Gate.net/publication/273259879.

- Mendaglio, S., \& Tillier, W. (2006): Dabrowski's theory of positive disintegration and giftedness: Over excitability research findings. Educational Journal for the gifted. 30(1), 68-87.

- Motamedi, F., \& Bonab, B. \& Farzi, (2017): A Study of Achievement, Motivation and Locus of Control in Gifted and NonGifted Students. The International Journal of Indian Psychology. 4(4), 55-59.

- Ocak, G. \& Boyraz, S. (2016): Examination of the relation between academic procrastination and time management skills of undergraduate students in terms of some variables. Journal of education and training studies. 4(5), 76-84.

- Renzulli, J. S., \& Smith, L. H., \& White, A. J., \& Callahan, C. M. \& Hartman, R. K., \& Westberg, K. L. (2002): Scales for Rating the Behavior Characteristics of Superior Students: Revised edition. Mansfield.

- Wolters, C.A.(2003): Understanding procrastination from selfregulated learning perspective. A Journal of Educational psychology, 95(1). 